\title{
PAINTING AT THE COURT OF EMPEROR SIGISMUND: THE NUREMBERG CONNECTIONS OF THE PAINTER THOMAS DE COLOSWAR
}

\begin{abstract}
The first great figure of panel painting in medieval Hungary was the painter Thomas de Coloswar, whose only surviving work is the Calvary-altarpiece from Garamszentbenedek (Hronský Beňadik, Slovakia), preserved today at the Christian Museum of Esztergom. The altarpiece was completed in 1427, and was commissioned by Nicholaus, son of Peter of Garamszentbenedek, cantor of the royal chapel at Buda castle. Generations of Hungarian and foreign researches have dealt with the significance and origins of this great work, and discussed the likely origins of its painter. In recent scholarship, there seems to be an agreement that the style of the painter stems from the International Gothic style of the Prague court - a style also incorporating French, Burgundian and Italian elements. It has also been suggested that the painter may have left Prague for Hungary at the time and because of the Hussite revolution. In my paper, I would like to demonstrate instead that the origins of the painting style of Master Thomas are to be found in Nuremberg, at the beginning of the fifteenth century. Thomas de Coloswar is closely connected to Nuremberg workshops around 1420, which developed after the completion of the main altar of the Frauenkirche in Nuremberg. Iconographic, stylistic, and historical observations will be discussed to support this proposition, which gives us a chance to re-evaluate painting at the court of King Sigismund as well. Observations concerning the portrait of Emperor Sigismund in Nuremberg and on the Calvary-altar from Garamszentbenedek are also included, as they strongly support the connection outlined in the study.

Keywords: Gothic painting, International Gothic, art of the fifteenth century, Esztergom, Christian Museum of Esztergom, Garamszentbenedek, Nuremberg, Prague, Thomas de Coloswar, patronage, Emperor Sigismund, Passion iconography
\end{abstract}

Contrary to sculpture or goldsmith works, very few surviving artworks provide information about panel painting at the court of King and Emperor Sigismund. No altarpieces or individual paintings survive which are proven to have been commissioned by him, and there are also relatively few manuscripts known from his possession. The situation is not better in the chief territorial base of his power, the Kingdom of Hungary, where he ruled as king from 1387 to 1437. In this situation, paintings that can be connected to important members of his court grow in importance and are regarded as indicators of a court style. This is the case with the Calvary-altarpiece of Thomas de

* Zsombor Jékely PhD, Museum of Applied Arts, Budapest; Department of Art History, Károli Gáspár University of the Reformed Church, Budapest; email: jekely@gmail.com
Coloswar, painted for the town of Garamszentbenedek (today Hronsky Beňadik, Slovakia) and preserved in the Christian Museum (Keresztény Múzeum) of Esztergom (Fig. 1). ${ }^{1}$ The altarpiece was painted in 1427 according to the lost inscription of its predella, and it has a monumental painted Crucifixion panel as its centerpiece, with only the cross of Christ rising among the multitude of figures depicted $(242 \times 177 \mathrm{~cm})$. The commissioner of the altar, a chaplain of the royal chapel, is depicted praying at the foot of the cross. Four other scenes from the Passion of Christ - Christ on the Mount of Olives, the Carrying of the Cross, the Resurrection and the Ascension of Christ form a complete narrative in the open altarpiece, which reads from left to right, in a U-shaped arrangement of the scenes. With the wings closed, the altarpiece shows miracles of popular saints: scenes from the life of Saint 

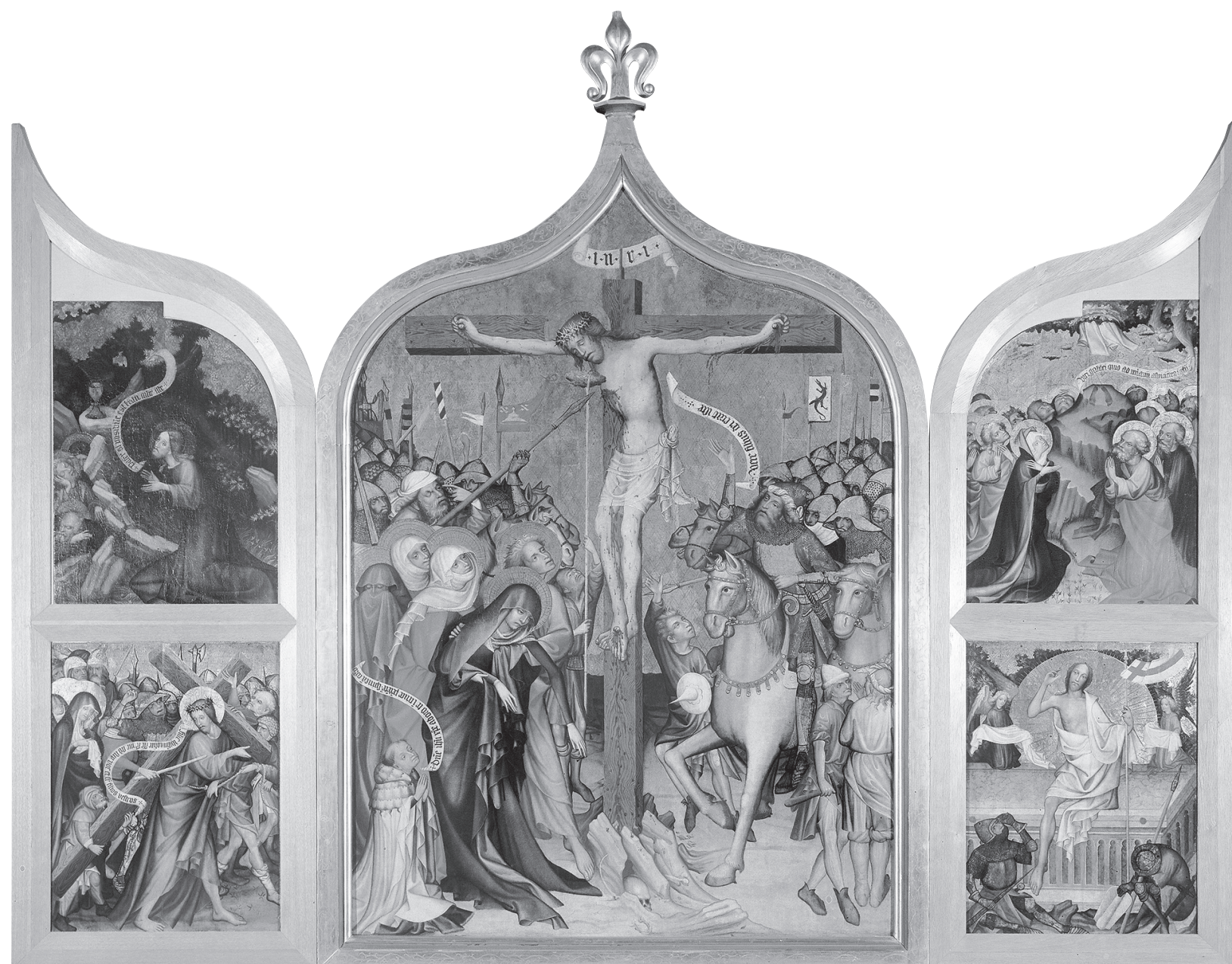

Fig. 1. Thomas of Coloswar: Calvary-altarpiece from Garamszentbenedek, open state with scene of the Passion of Christ; Esztergom, Christian Museum (photo: Christian Museum, Attila Mudrák)

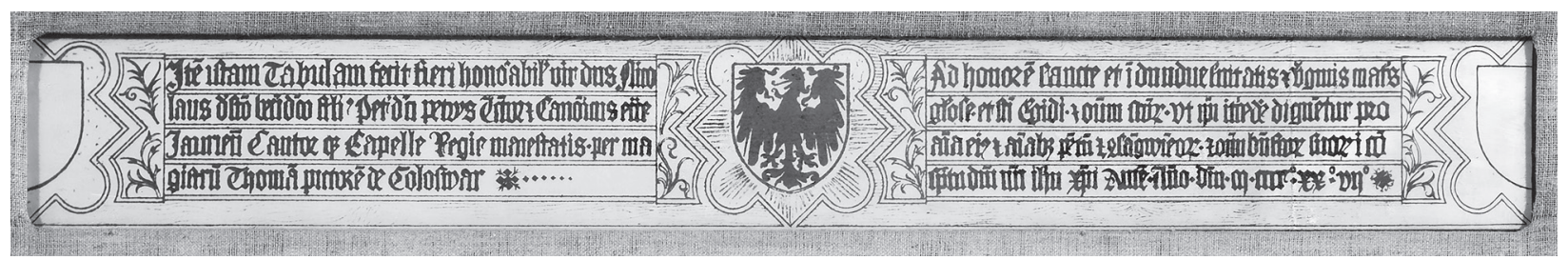

Fig. 2. Reconstruction of the predella of the Calvary-altarpiece of Thomas of Coloswar, based on a drawing published by Knauz 1890; Esztergom, Christian Museum (photo: Christian Museum, Attila Mudrák)

Benedict, Saint Giles and Saint Nicholas (the wings had been sawn in half, and one of the exterior panels got lost over the centuries). ${ }^{2}$

The altarpiece was recorded at the Benedictine Abbey of Garamszentbenedek at the beginning of the nineteenth century, and by around 1870 it was in the collection of Esztergom archbishop János Simor, which formed the nucleus of the later Christian Museum of Esztergom. ${ }^{3}$ Simor collected several late medieval artworks from the abbey of Garamszentbenedek, which was under his jurisdiction. The predella of the altar- piece is only known from an 1885 drawing by Franz Storno, as it got destroyed in a fire at the Museum in 1905 (Fig. 2). ${ }^{4}$ The predella contained an inscription, which inform us that the altarpiece was commissioned by Nicholas, chaplain of the royal chapel, in 1427, and was painted by Master (magister) Thomas, painter from the Transylvanian town of Kolozsvár (Klausenburg, today Cluj-Napoca, Romania). ${ }^{5}$ Although debated in the past, we can accept the strong arguments supporting that the altarpiece and the lost predella belonged together, and they arrived together to Esztergom from 


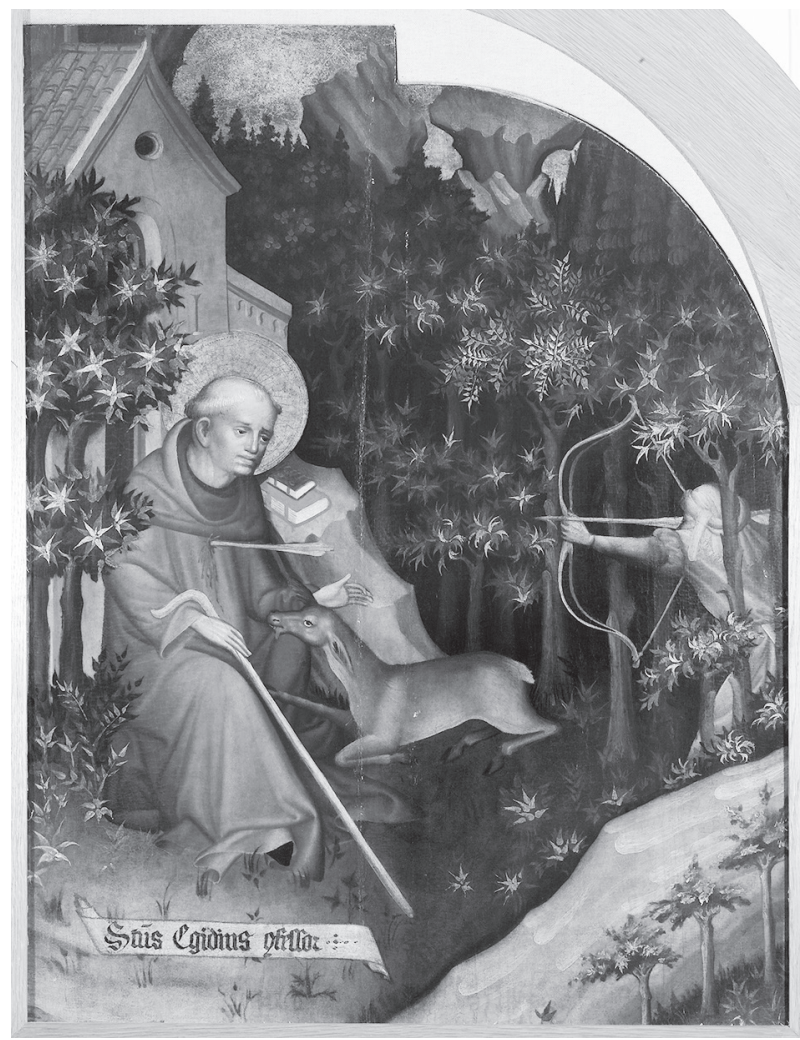

Fig. 3. Thomas of Coloswar: Scene from the legend of St. Giles, from the outside of the Calvary-altarpiece from Garamszentbenedek; Esztergom, Christian Museum (photo: Christian Museum, Attila Mudrák)

Garamszentbenedek. Even though the predella was first recorded in the abbey, it has also been suggested that the altar was originally commissioned for the parish church of Garamszentbenedek, the patron saint of which was Saint Giles. ${ }^{6}$ The parish church was the likely resting place of the parents of the commissioner, as he calls himself "of Szentbenedek" (de sancto benedicto). Given that the royal abbey was the most prestigious institution in the town, it seems more likely that the Calvary-altar originally stood there - possibly marking the Holy Cross altar in front of the former choir screen (Fig. 3).

In the framework of the present paper, I do not wish to dwell more on the history of the altarpiece accepting its date of 1427 and Thomas de Coloswar as its painter, I would like to focus on the artistic origin of this master. This issue has been a central topic of publications about the altarpiece, ever since the first monographic treatment of the altarpiece by Tibor Gerevich in 1923. ${ }^{7}$ At that time the panels still showed the effect of a restoration and overpainting carried out in the late nineteenth century and in 1915, which heavily affected some scenes, especially

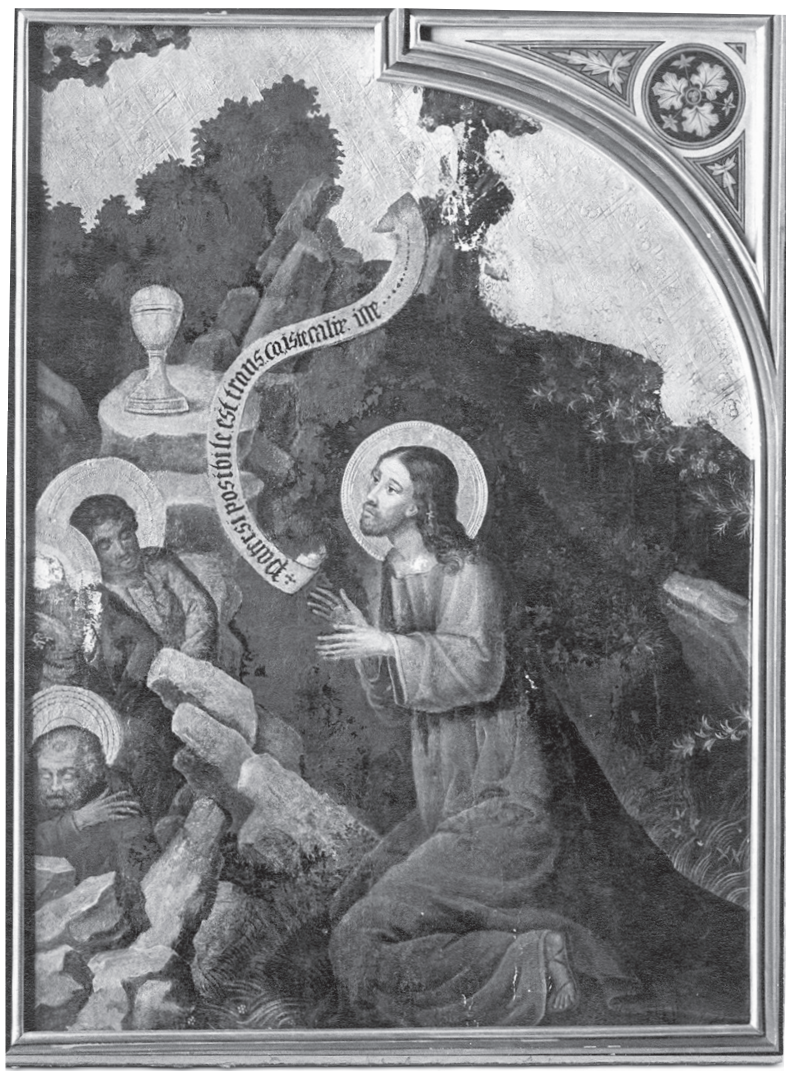

Fig. 4. Thomas of Coloswar: Christ on the Mount of Olives from the Calvary-altarpiece from Garamszentbenedek, state before the restoration of Lajos Nikássy in the 1930s

the scene of Christ on the Mount of Olives ${ }^{8}$ (Fig. 4). Gerevich emphasized the connection of the Passion scenes to German painting (mentioning the Rhein area and Cologne specifically), and called attention to the Italian parallels of the external panels with the scenes from the lives of saints - although he attributed all of the panels to the same master. István Genthon argued along similar lines in the first monograph dedicated to Hungarian medieval painting, while also pointing out a relationship with Silesia. ${ }^{9}$ He also emphasized the connection of the painter to the royal court of Buda, referring to the patron, who was chaplain of the royal chapel. ${ }^{10}$ He was also the first one to recognize that the figure of the Centurion in the central panel is a disguised portrait of Emperor Sigismund. ${ }^{11}$ Although the possibility of the painter's Italian connections was raised in later literature as well, it could not be proven. This aspect, even when noticed, has been described as secondary, appearing only through the filter of Central European painting. ${ }^{12}$ Several researchers attempted to connect the painter with early Netherlandish painting - Zsuzsa Lukács in 1973 called attention to this aspect, ${ }^{13}$ and more recently Györgyi Poszler brought 
relevant analogies to support this possibility. ${ }^{14} \mathrm{How}-$ ever, research could only point to rather general similarities with the art of the South Netherlands - even Poszler acknowledged that connections with FrankoFlemish art, specifically with the Antwerp-Baltimore quadriptych is not direct.

Another avenue of research tied the painter to Bohemian or, more generally, southern German painting $^{15}$ - observations in this direction were summarized by Dénes Radocsay in his catalogue of Hungarian medieval panel painting (1955). ${ }^{16}$ Instead of the rather general similarities with the Třebon altarpiece and the Rajhad altarpiece (at that time dated to the 1420s), Gyöngyi Török called attention to more specific stylistic analogies. ${ }^{17}$ She pointed to the workshop of the famous Bohemian illuminators associated with the Gerona Martyrology. ${ }^{18}$ She also called attention to the very close similarities of the faces painted by Master Thomas to those in the famed Vienna Model Book. ${ }^{19}$ This collection of miniature drawings of facial types from the repertoire of an itinerant painter is attributed to a Bohemian master mainly because of a close stylistic affinity with the workshop of the Gerona Martyrology. Gyöngyi Török has introduced a series of close comparisons between faces in the Model Book and those painted by Thomas de Coloswar. More recently, Mojmir Frinta, Milena Bartlová, and Györgyi Poszler made meaningful comparisons with the Martyrology manuscript itself, and with related manuscripts, such as the Antwerp (or Vechta Bible), the London manuscript of the Travels of Mandeville, and with the cuttings from the luxurious Sedlec antiphonaries (Figs. 5-6).$^{20}$ It has also been demonstrated - primarily by Milada Studničkova - that illuminators from the workshop of the Gerona Martyrology in fact entered the service of King Sigismund, and some even worked for Hungarian commissioners. ${ }^{21}$ This can be detected in the field of manuscript illumination: the title page miniature of the Antiphonal IV from Pozsony and a series of armorial letters issued by King Sigismund at Constance in 1418 are among the evidence. ${ }^{22}$

More recently, Jan Klípa also pointed out that Thomas de Coloswar must have been familiar with the art of Prague in the time before the Hussite uprising, and may have transferred from Prague to Buda. Klípa, however, also suggests that the Vienna Model Book may have been in Buda at this time as well. ${ }^{23}$ Ernó Marosi describes Thomas de Coloswar as a characteristic example of émigré painters fleeing from Prague after $1415 .{ }^{24}$ It was in this context that the painter was discussed in some recent catalogues and confer-

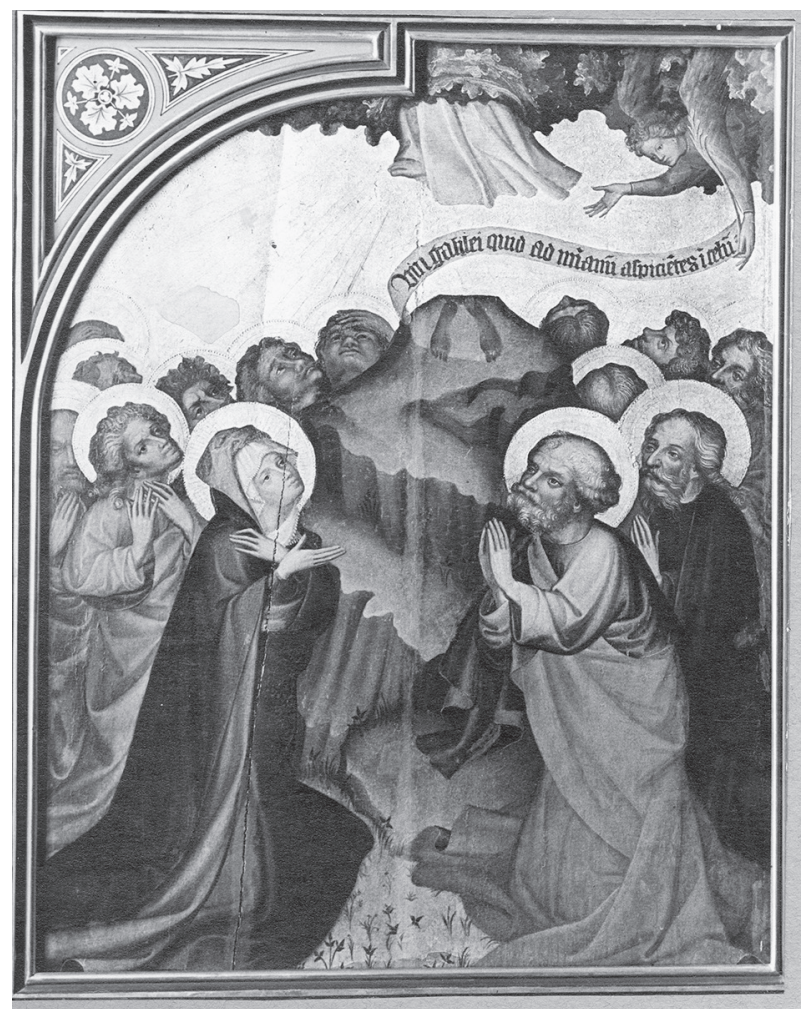

Fig. 5. Thomas of Coloswar: Scene of the Ascension from the Calvary-altarpiece from Garamszentbenedek, state before the restoration of Lajos Nikássy in the 1930s

ence volumes, published on occasion of the New York and Prague exhibitions dedicated to the Luxemburg dynasty. 25

Comparisons with the Gerona Martyrology workshop and related early fifteenth century works, however, also raise several problems: first of all, most comparisons were made only with the scenes from the lives of saints on the exterior of the altarpiece, and not with the Passion cycle. For the composition and iconography of the Passion scenes, no meaningful analogies have been found so far in this group of miniatures, apart from a few faces in the Vienna Model Book. It is also problematic to suppose that someone trained in the art of miniature painting would suddenly create one of the most monumental painted altarpieces of the period. The question of the Passion scenes is usually settled with a general reference to Bohemian painting of the Beautiful style, in particular to the Master of the Třeboñ Altarpiece - even though no-one would suggest a direct connection between an altarpiece from 1427 and another generally dated to around $1380 .{ }^{26}$ The Rajhad altarpiece, another comparison often cited since the influential article of Ludwig Baldass, has more recently been dated to much later than the Garamszentbenedek altar - Milena Bartlová suggested a date 


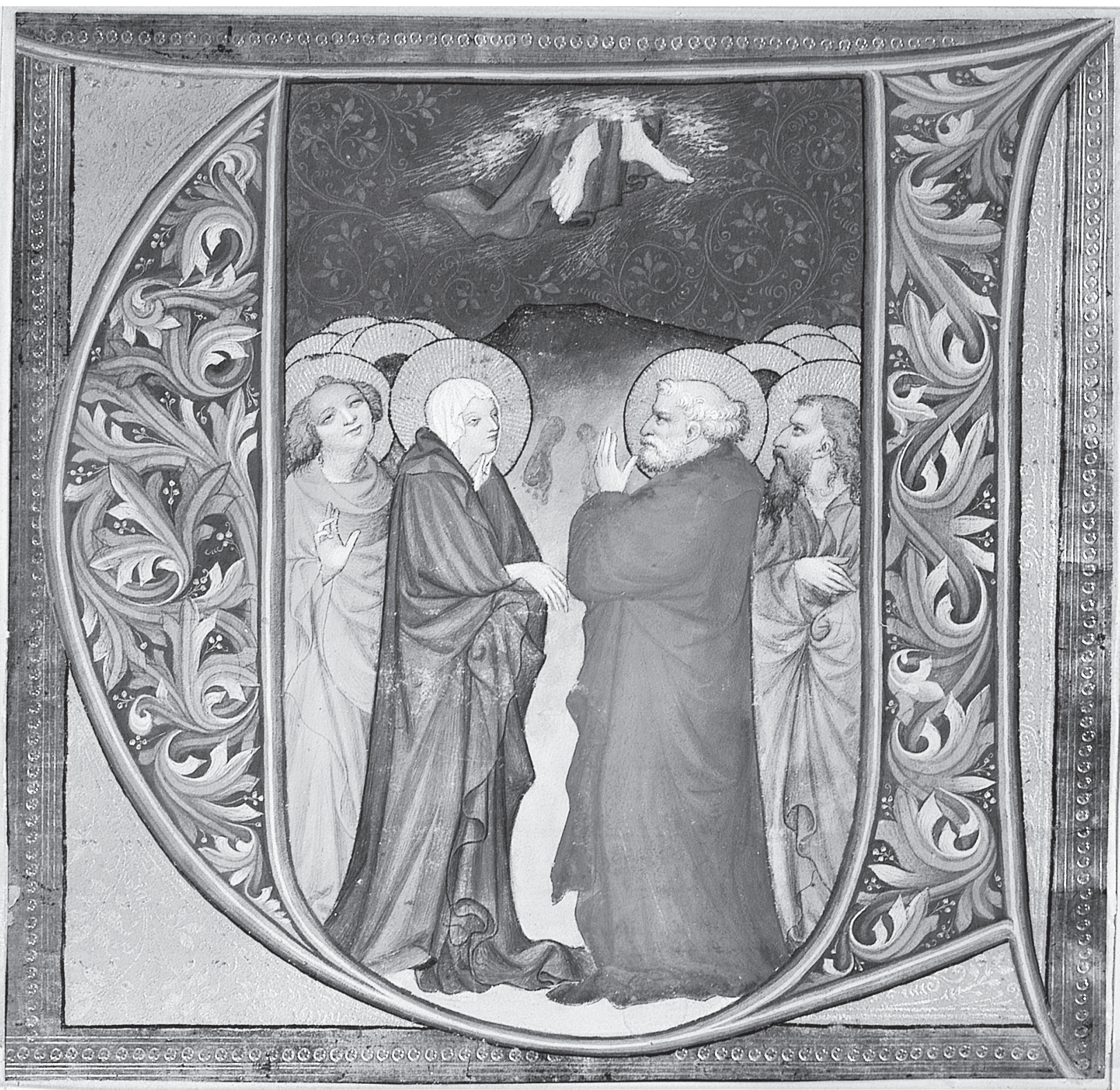

Fig. 6. Scene of the Ascension on an initial cut from an antiphonary of the monastery of Sedlec, c. 1414; Budapest, Szépmúvészeti Múzeum (photo: Attila Mudrák)

as late as 1452, while most scholars now accept a date of around 1440.27 Parallels brought with other examples of Bohemian painting - such as the so-called Capuchin cycle of apostles from Prague - are less convincing, especially due to the great difference in quality. ${ }^{28}$

In the present paper, I would like to argue that there is another component to the art of Thomas de Coloswar, which appears to be more important and more direct than connections to Prague around 1400. I would like to focus on connections with early fifteenth century painting in the imperial city of Nuremberg, while also attempting to ground the art of the master more firmly in court art of the period of Sigismund in the Kingdom of Hungary. ${ }^{29}$ These connections appear to be much more direct, suggesting that the artistic origins of the master should not be sought in Prague, but instead in Nuremberg.

Iconography of the Passion scenes and the program of the altarpiece

First, I would like to investigate the iconography of the Passion scenes of the altarpiece of Thomas de Coloswar, comparing them to works made in Nuremberg, starting with the great altarpiece made as the 


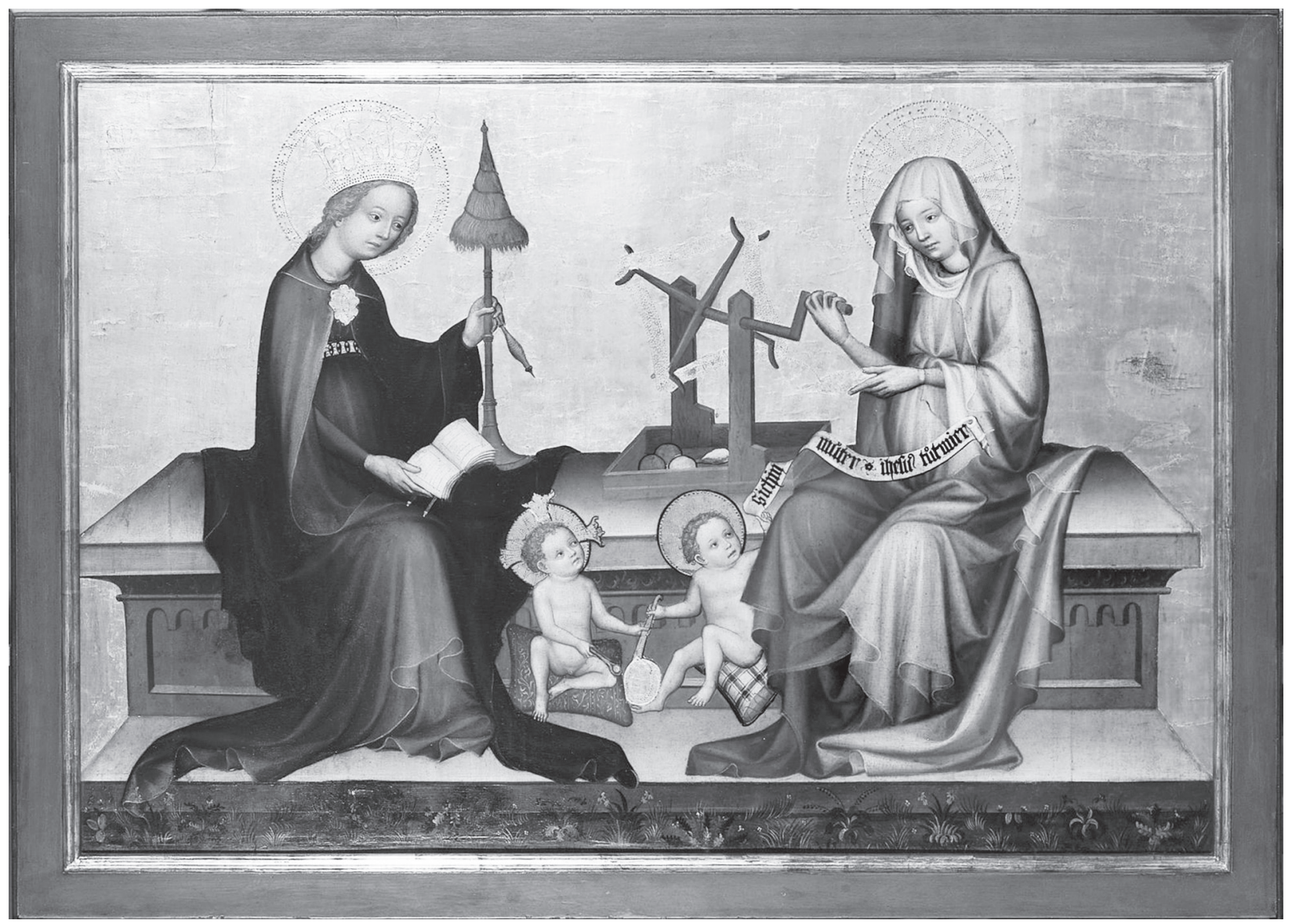

Fig. 7. The Virgin Mary and Saint Elizabeth with their children, inside panel of the main altar of the Frauenkirche in Nuremberg, 1400-1410; Nuremberg, Germanisches Nationalmuseum

main altar for the Frauenkirche at the beginning of the fifteenth century. ${ }^{30}$ The Frauenkirche was established by Emperor Charles IV in 1355, after the raising of the Jewish quarter of Nuremberg in 1349. ${ }^{31}$ The church was consecrated in 1358, although its sanctuary - and main altar - was only completed in 1360 . The church had the function of a royal chapel, and remained directly under royal patronage. Nothing is known of the decoration of the original main altar, dedicated to the Virgin - there may only have been a statue of the Virgin there. The new altarpiece was erected around 1400 or somewhat thereafter, likely commissioned by a group of patricians, Michael Behaim among them. ${ }^{32}$ This new altarpiece has recently been reconstructed and analyzed in detail by Gerhard Weilandt, the foremost authority on the medieval churches of Nuremberg. ${ }^{33}$ Weilandt provides ample proof that this dispersed altarpiece - the panels of which had been sawn in half and are now in the Germanisches Nationalmuseum in Nuremberg and at the Städel Museum in Frankfurt - once stood in the sanctuary of the Frauenkirche. The inner side was dedicated to the patron of the church, the Virgin Mary, with a terracotta group of the Death of the Virgin in the center. ${ }^{34}$ On the two sides, a total of four scenes illustrated the life of the Virgin, focusing on scenes connected to relics preserved in the $\operatorname{church}^{35}$ (Fig. 7). In a closed state, the exterior side had four large images depicting events of the Passion of Christ (Fig. 8). These paintings have long been recognized as the primary examples of Bohemian influence in Nuremberg, and also as firstrate works of the Central European Beautiful Style. ${ }^{36}$ The style of the panels is most closely related to the workshop of the Trreboñ (Wittingau) master, and also to the generation of painters directly following this workshop at the end of the fourteenth century - thus the workshop of the Jeržen epitaph in Prague. At this time the expansion of this characteristic Prague style can be detected in several regions - notable examples include in Silesia the Strzegom St. Anne with the Virgin and Child, and in the Pomeranian territory of the Teutonic Knights the great altarpiece from Grudziądz, now at the National Museum in Warsaw. ${ }^{37}$ In Nuremberg, the altarpiece of the Frauenkirche was the semi- 


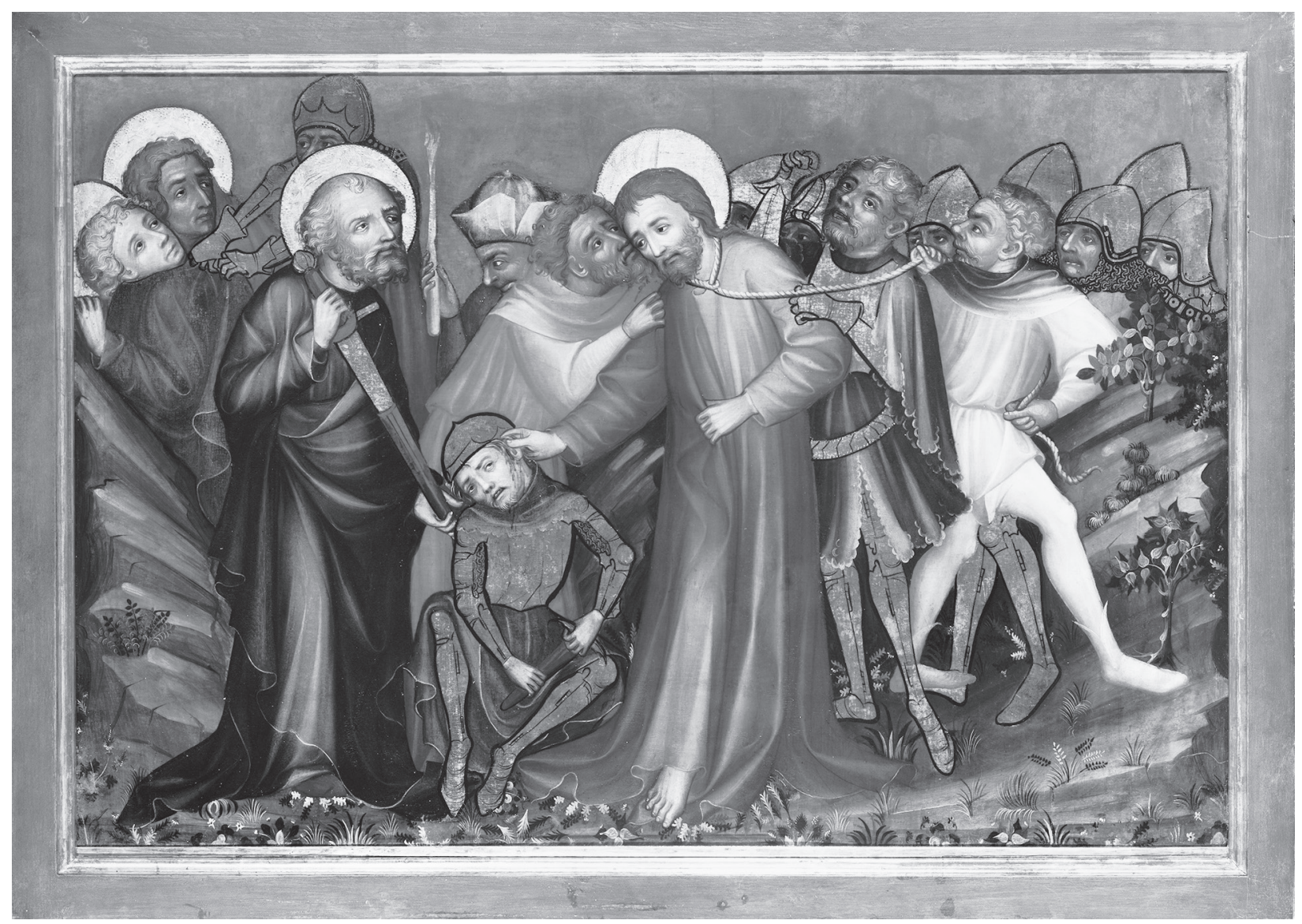

Fig. 8. Arrest of Christ, outside panel of the main altar of the Frauenkirche in Nuremberg, 1400-1410; Nuremberg, Germanisches Nationalmuseum

nal work which essentially created a new chapter in the artistic development of the town, bringing the full-fledged Beautiful style there. It can also be said that the altarpiece provides a bridge from Bohemian art to Nuremberg painting of the 1420s, as we can see a noticeable flourish of artistic production in the first decades of the fifteenth century. Several altarpieces have been described as the direct followers of the Master of the Nuremberg altar of the Virgin. Here we should mention those Passion altarpieces which are most relevant for our argument: first of all, the Bornhofen altarpiece, which was painted by Master Berthold von Nördlingen in 1415 (today divided between Darmstadt, Hessisches Landesmuseum and Bonn, Rheinisches Landesmuseum; Fig. 9). The painter was almost certainly trained in Nuremberg, in the environment of the workshop of the main altar of the Frauenkirche, but also was directly familiar with Bohemian painting. ${ }^{38}$ The altarpiece was completed in 1415 , according to an inscription on its lost predella, and was commissioned by the Katzenelnbogen family, counts in the service of Sigismund. In its closed state, the altarpiece had a series of rectangular panels arranged in two rows, each panel depicting two scenes from the Passion of Christ - with the patrons appearing next to the seventh and last scene, the Crucifixion. The painter, Master Berthold died in 1422, as we know from a charter issued by Sigismund - here his widow is mentioned, whose cousin, Konrad was about to become the abbot of the Cistercian royal abbey of Pilis (near Buda). Wilfried Franzen, who has studied the altarpiece most recently, describes it as a characteristic piece from the court environment of Sigismund, which was commissioned from a painter from an imperial city just about half a year after the coronation of Sigismund in Aachen. ${ }^{39}$

Second, the great Crucifixion-altarpiece from the Franciscan church of Bamberg must be mentioned (today at the Bayerisches Nationalmuseum in Munich; Fig. 10). ${ }^{40}$ Dating from 1429, the monumental altarpiece originally stood in front of the rood screen of the church of St. Anne. The program of the Bamberg altarpiece is quite similar to the Garamszentbenedek altar: its large painted central panel is dedicated to the 
Crucifixion, and is surrounded by two other scenes of the Passion narrative: The Carrying of the Cross, and the Deposition. On the exterior, in closed state, two further Passion scenes are painted: The Crowning with Thorns, and Christ before Pilate. The workshop responsible for this monumental altarpiece was based in Nuremberg, and the altarpiece best represents a new kind of solution for painting large-scale, multi-
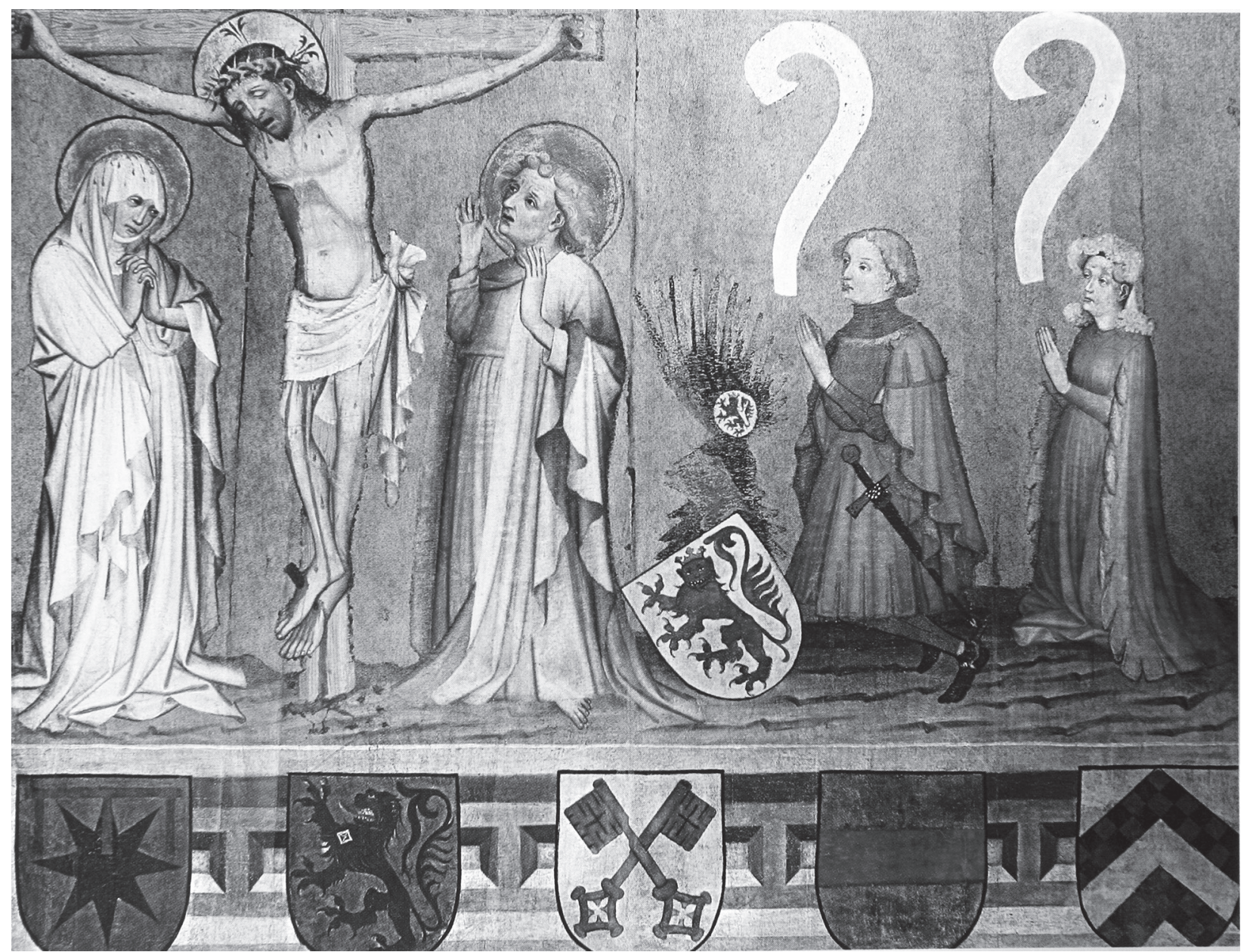

Fig. 9. Calvary scene and donors, from the Bornhofen altar, 1415; Bonn, Rheinisches Landesmuseum

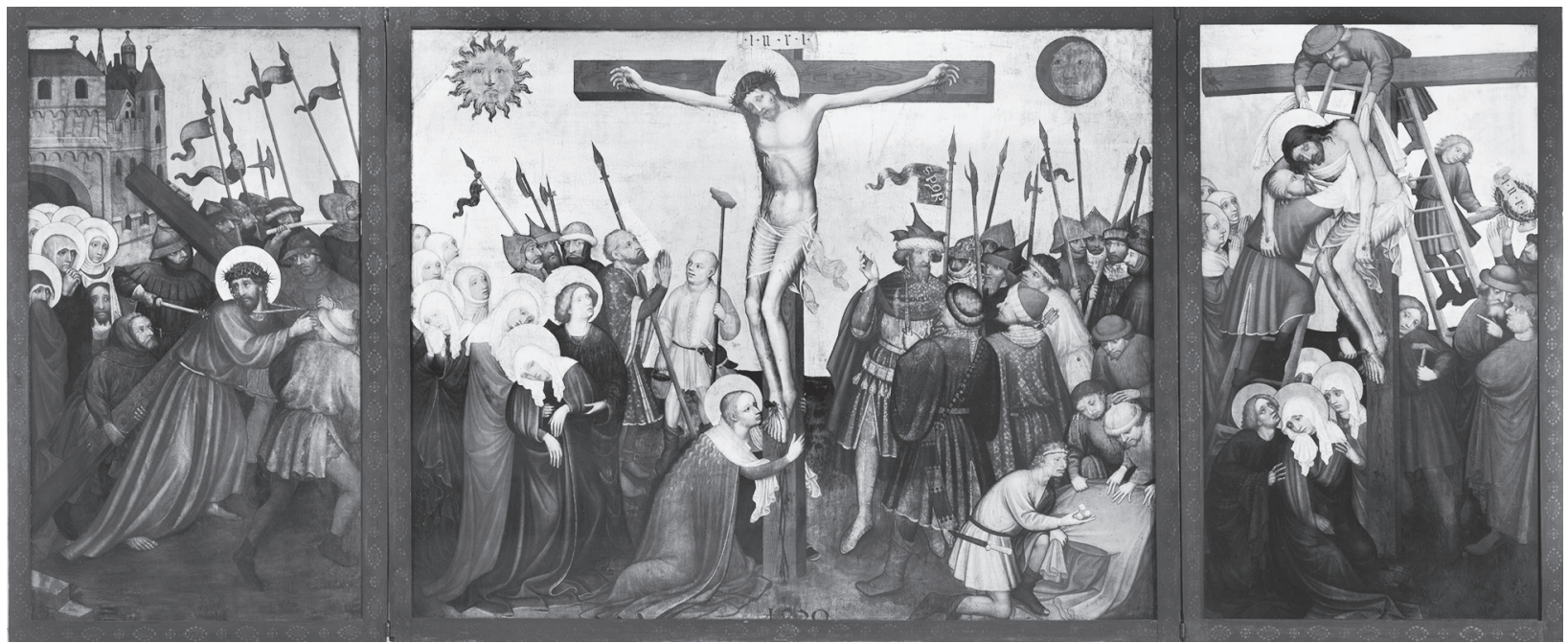

Fig. 10. Calvary-altarpiece from the Franciscan church of Bamberg, 1429; München, Bayerisches Nationalmuseum 
figure Calvary scenes. ${ }^{41}$ Passion scenes on these two altarpieces, and on the main altar of the Frauenkirche itself, show a close affinity with the scenes painted by Thomas de Coloswar, and meaningful comparisons can be made with several scenes. In making these comparisons, I will proceed in the order of the narrative of the Garamszentbenedek altarpiece.

Christ on the Mount of Olives is the first panel of the Passion narrative of the Garamszentbenedek altar (Fig. 11). This is a reversed and more compact variant of the corresponding panel from the main altar of the Frauenkirche in Nuremberg (Fig. 12). ${ }^{42}$ Christ and the three apostles present are separated by a row of jagged rocks, and the chalice ("Pater [mi] si possibile est, transeat [a me] calixiste" according to the inscription, with text from the Gospel of Matthew, 26:39) is in the focus of the paintings. Much of the Garamszentbenedek panel is a reconstruction, as this panel suffered serious damage at an unknown time but the composition is authentic. ${ }^{43}$ The Nuremberg panel is said to derive from the famous composition of the Trrebon altarpiece, now at the National Gallery in Prague. However, its painter focuses more clearly on the central elements of the narrative, by leaving out the group of soldiers approaching, and the angel appearing to Christ (the panel has been cut down on all sides, but not so much as to fully obliterate such elements). Thomas de Coloswar follows this focused composition, and he further diminishes the apostles by sticking them into the lower corner of the panel. The corresponding composition on the Bornhofen altar is also similar, although the grouping of the figures is reversed: the group of the apostles are depicted behind the back of Christ (and the figure of God appears above the chalice).

The second scene of the Garamszentbenedek altar depicts the Carrying of the cross (Fig. 13). This scene was not included on the retable of the Frauenkirche, but is present on the next important altarpiece painted by a Franconian workshop, the Bornhofen retable (Fig. 14). We can see that both painters follow the same type of composition: Christ carries his cross behind him, Simon of Cyrene - depicted as an old, small, bearded, hooded man - holds the lower end of the cross, a soldier leads Christ on a rope, and Christ glances backwards, where his mother follows. A similar, although somewhat more crowded scene appears on the great retable from the Franciscan church of Bamberg (1429). All these paintings show the cross and most auxiliary figures placed behind Christ, as it became widespread by the beginning of the fifteenth century. ${ }^{44}$

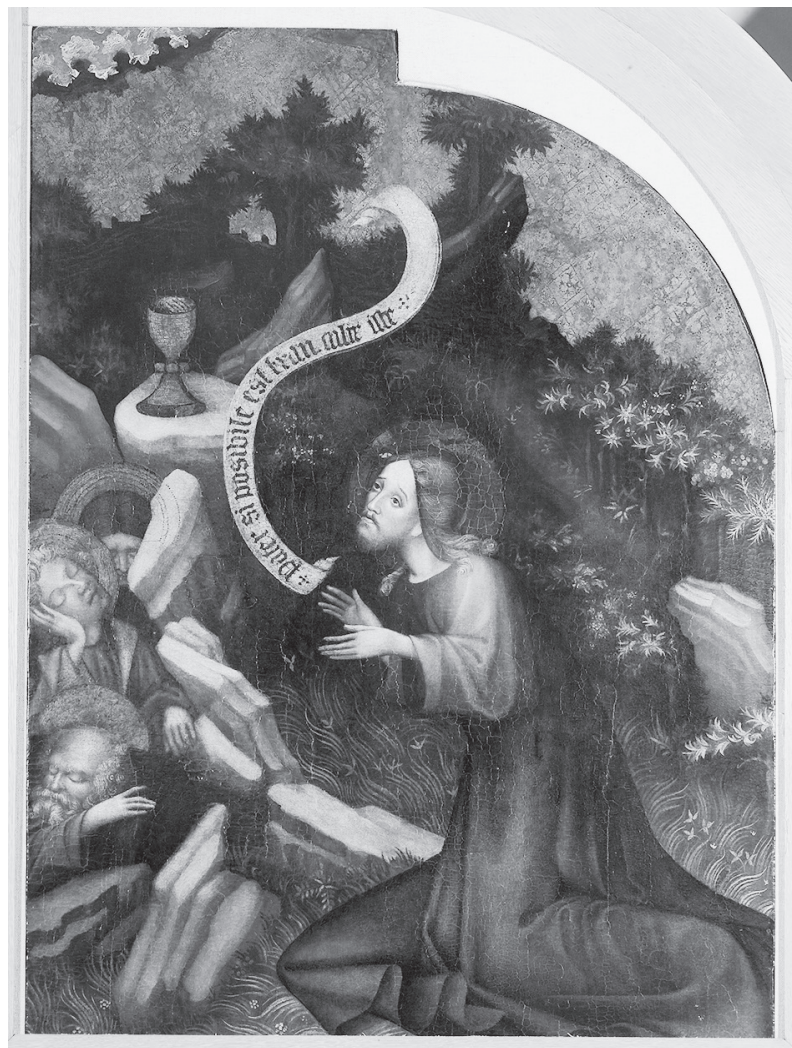

Fig. 11. Thomas of Coloswar: Christ on the Mount of Olives, 1427; Esztergom, Christian Museum (photo: Christian Museum, Attila Mudrák)

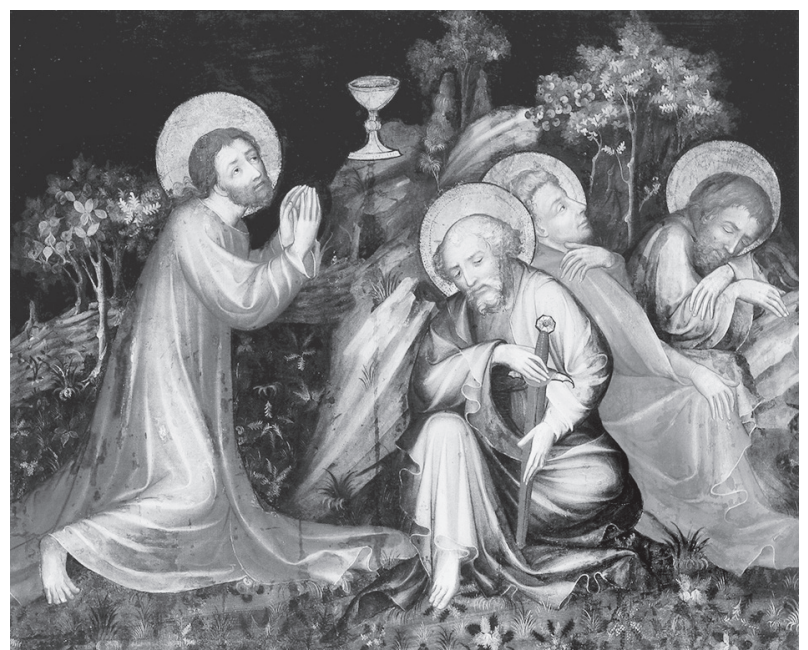

Fig. 12. Christ on the Mount of Olives, outside panel of the main altar of the Frauenkirche in Nuremberg, 1400-1410; Frankfurt, Städel Museum

The Crucifixion on the central panel represents the next stage and the climax of the narrative (Fig. 15). In this case, a close comparison can be made with the Bamberg altarpiece (Fig. 16), as the other two works only had three-figure Crucifixion scenes (only fragments survive from the Nuremberg panel). ${ }^{45}$ Both 


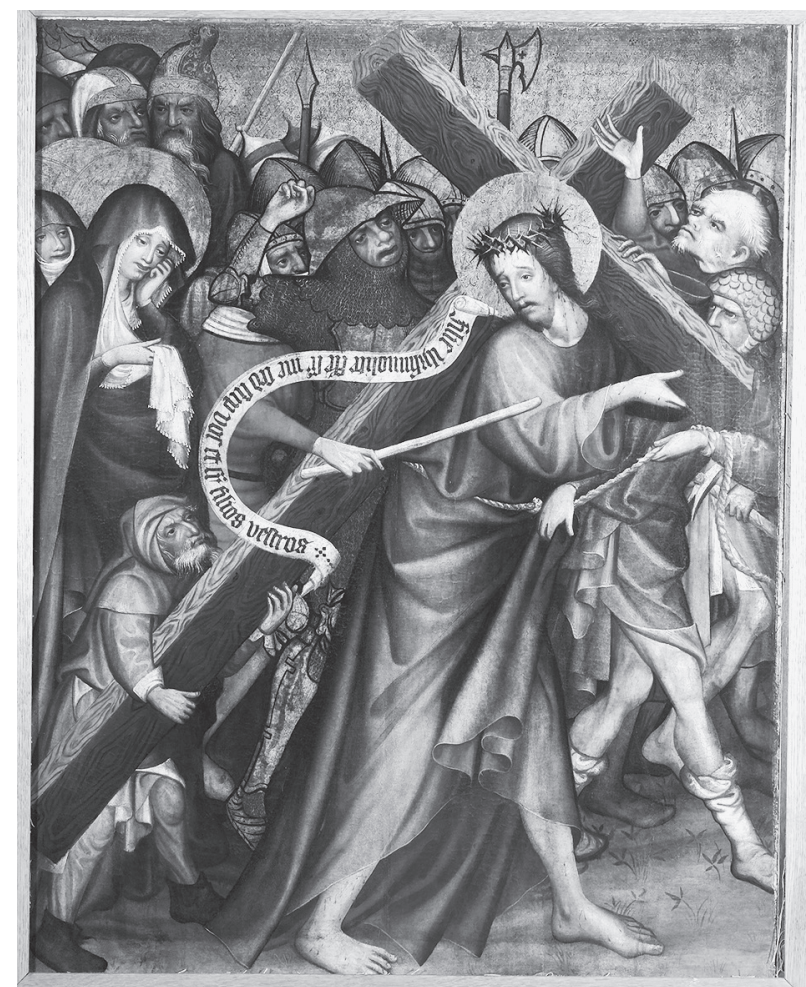

Fig. 13. Thomas of Coloswar: Carrying of the Cross, 1427; Esztergom, Christian Museum

(photo: Christian Museum, Attila Mudrák)

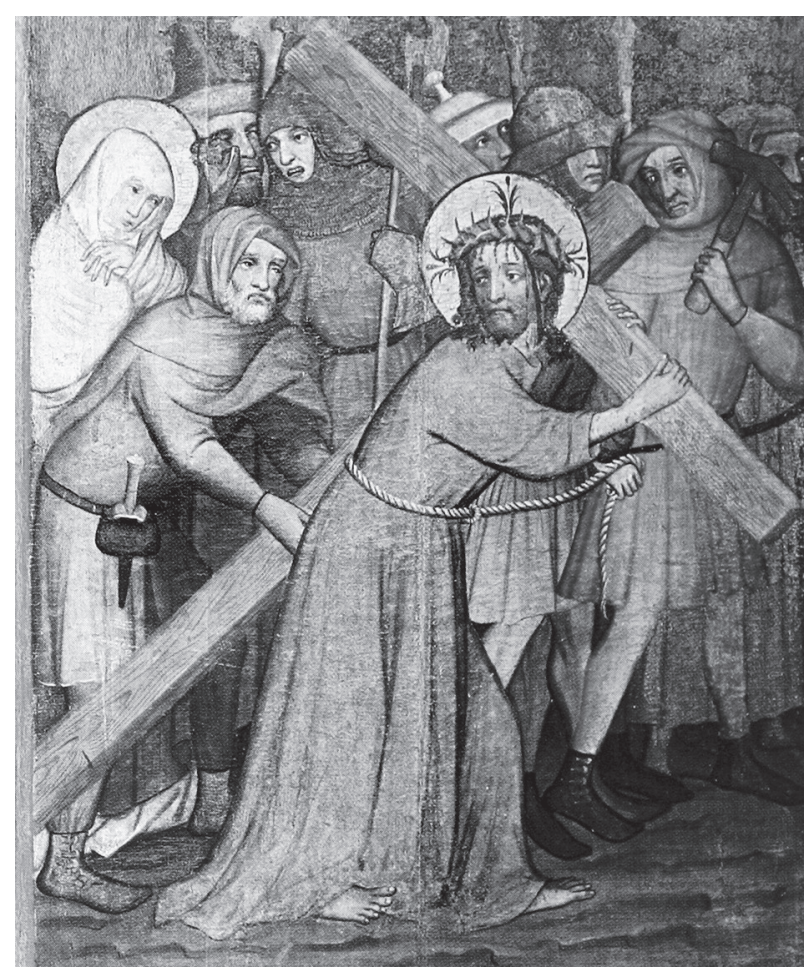

Fig. 14. Carrying of the Cross, scene on the outside of the Bornhofen altar, 1415; Bonn, Rheinisches Landesmuseum

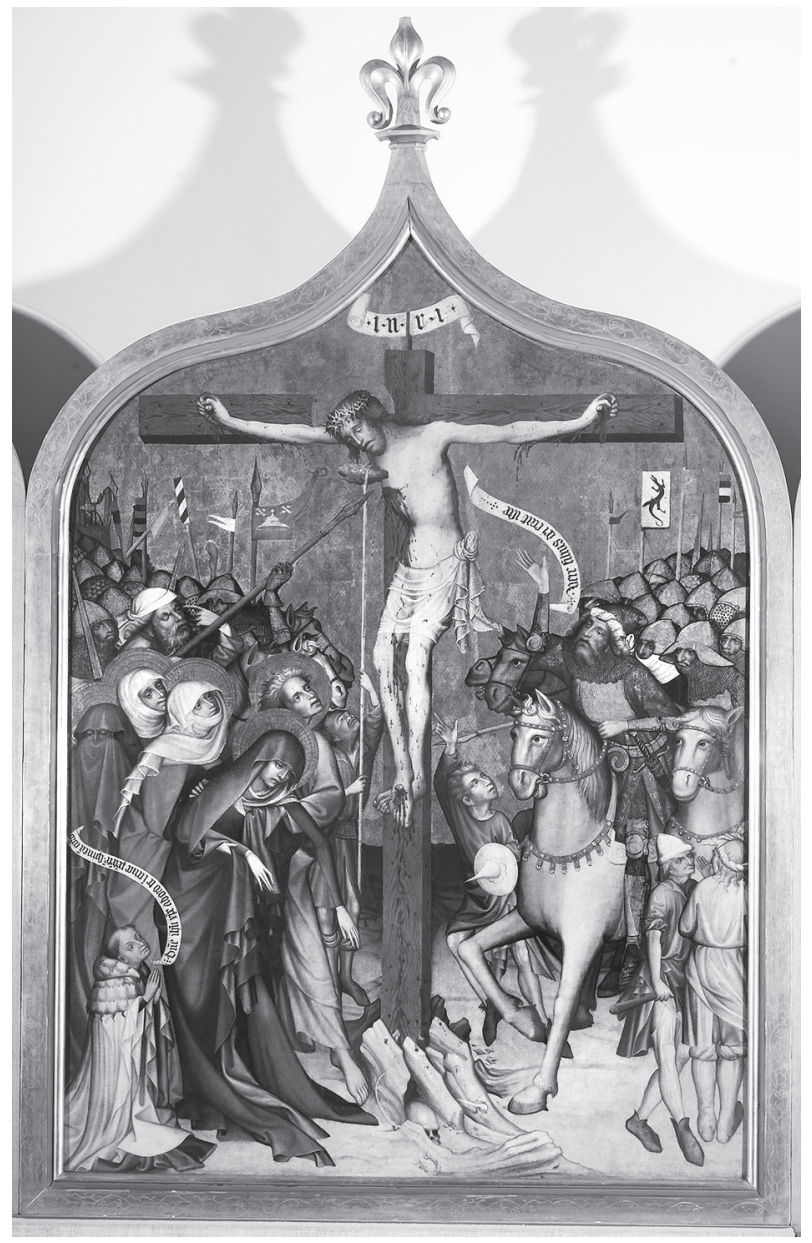

Fig. 15. Thomas of Coloswar: Calvary scene from the center of the Garamszentbenedek altar, 1427; Esztergom, Christian Museum

(photo: Christian Museum, Attila Mudrák)

at Garamszentbenedek and at Bamberg, figures are grouped on two sides of the cross of Christ, which rises high against the gold background of the panels (the crosses of the thieves are not depicted). In both cases, this large multi-figural Crucifixion panel was the centerpiece of the entire altar, which can be regarded as somewhat of a novelty at the time. Painting such populated (Volkreiche) Cruficixion scenes constituted one of the primary tasks of fifteenth century painters, as Robert Suckale argues. ${ }^{46}$ The Bamberg Crucifixion represents the starting point of Suckale's argument, and what he says about it, also applies to the altarpiece of Thomas de Coloswar. Both paintings emphasize the act of Salvation by isolating and elevating the figure of Christ on the cross in front of a gold background. Therefore, the crosses of the two thieves are completely left out. This multi-figural compositional type originates from the Italian Trecento painting, and already appeared north of the Alps in the fourteenth century. 


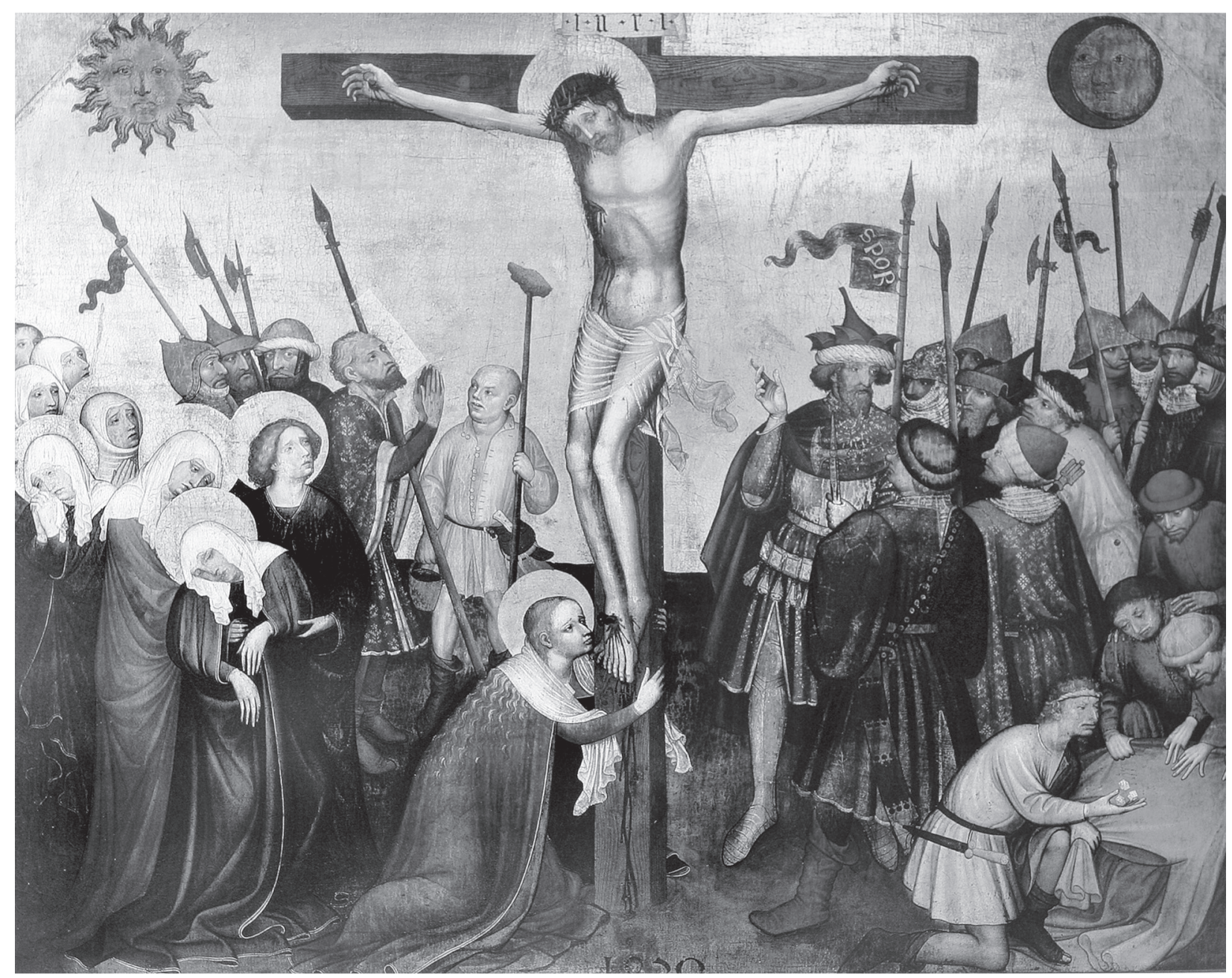

Fig. 16. Master of the Bamberg Altar: Calvary scene from the center of the Bamberg altar, 1429; München, Bayerisches Nationalmuseum

Two key examples are the painted Crucifixion panel of the Klosterneuburg altar (1331) and the so-called Kaufmann Crucifixion, now in Berlin (c. 1340) ${ }^{47}$ Not only the body of Christ, but also the cross itself is the focus of these paintings, which of course was the most important relic of Christendom, and of which a particle was preserved in Nuremberg along with the imperial coronation regalia. All this of course gained extra significance at the time of the Hussite conflict, leading to renewed interest in the picture type. The central panel of the Garamszentbenedek altar groups the figures similarly to the Bamberg altar (and to the Kaufmann Crucifixion): the mourning Virgins are on one side, and the Virgin Mary is supported by St. John, while the group centered around the Centurion is on the other side. Other examples of this type of composition in Nuremberg include a now lost wallpainting from the former Moritzkapelle next to the church of St. Sebald (Fig. 17). The fresco also depicts a multi-figure Crucifixion, with the cross rising above the other participants. ${ }^{48}$ The shape of the altarpiece of Thomas of Coloswar recalls this composition, which

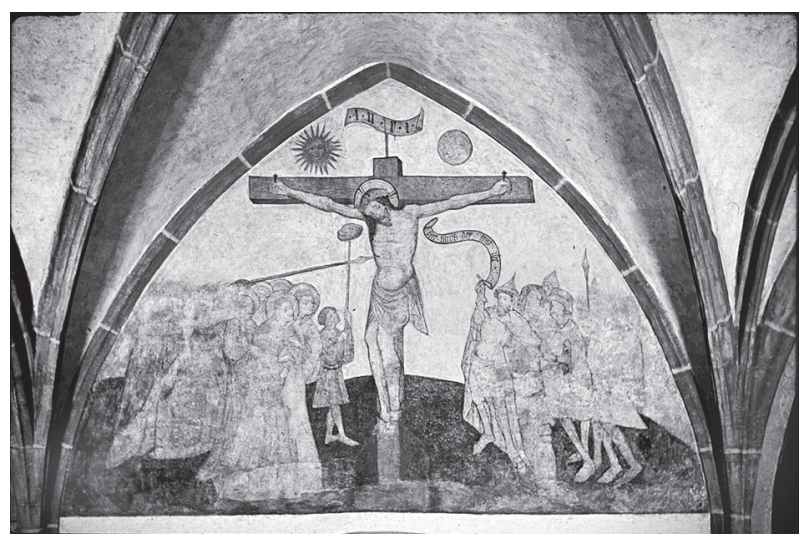

Fig. 17. Calvary scene, wall painting from the Moritzkapelle next to St. Sebald, Nuremberg (destroyed during WWII) (Photo: Farbdiaarchiv zur Wand- und Deckenmalerei, Zentralinstitut für Kunstgeschichte, München) 


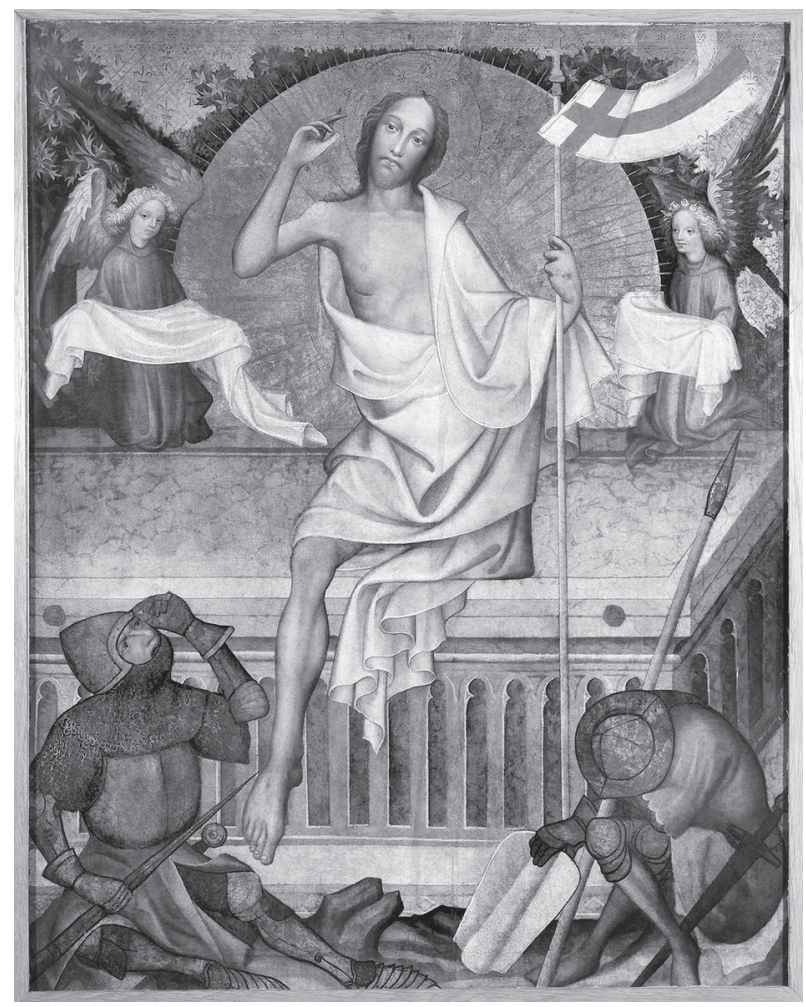

Fig. 18. Thomas of Coloswar: Resurrection, 1427; Esztergom, Christian Museum

(photo: Christian Museum, Attila Mudrák)

was fitted to the arched space under the vaults once covering the chapel.

Continuing the narrative, the panel on the lower right side of the Garamszentbenedek altar shows the Resurrection of Christ (Fig. 18). The scene is not part of either of the three altarpieces from the Nuremberg circle, which all focus on the suffering of Christ, and carry the narrative until the Crucifixion. Comparing the scene with the similar panel of the altar of Trebon, some commentators saw an error in the composition of Thomas de Coloswar. ${ }^{49}$ In both paintings, Christ miraculously emerges from the sealed tomb, but while on the Bohemian example he triumphantly floats above it, on the Hungarian painting one of his legs still seems to be inside the sarcophagus (thus it is not shown). As Györgyi Poszler argued, the movement of Christ is similar to Franko-Flemish works, specifically the scene in the Antwerpen-Baltimore quadriptychon - although there Christ emerges from an open sarcophagus. ${ }^{50}$ The combination of the "stepping out" movement and the sealed sarcophagus, however, is not the invention of Thomas de Coloswar nor is it some kind of misunderstanding - it is a known iconographic type of the early fifteenth century in Southern Germany. A print at the Hungarian Academy of Sciences, dating from around

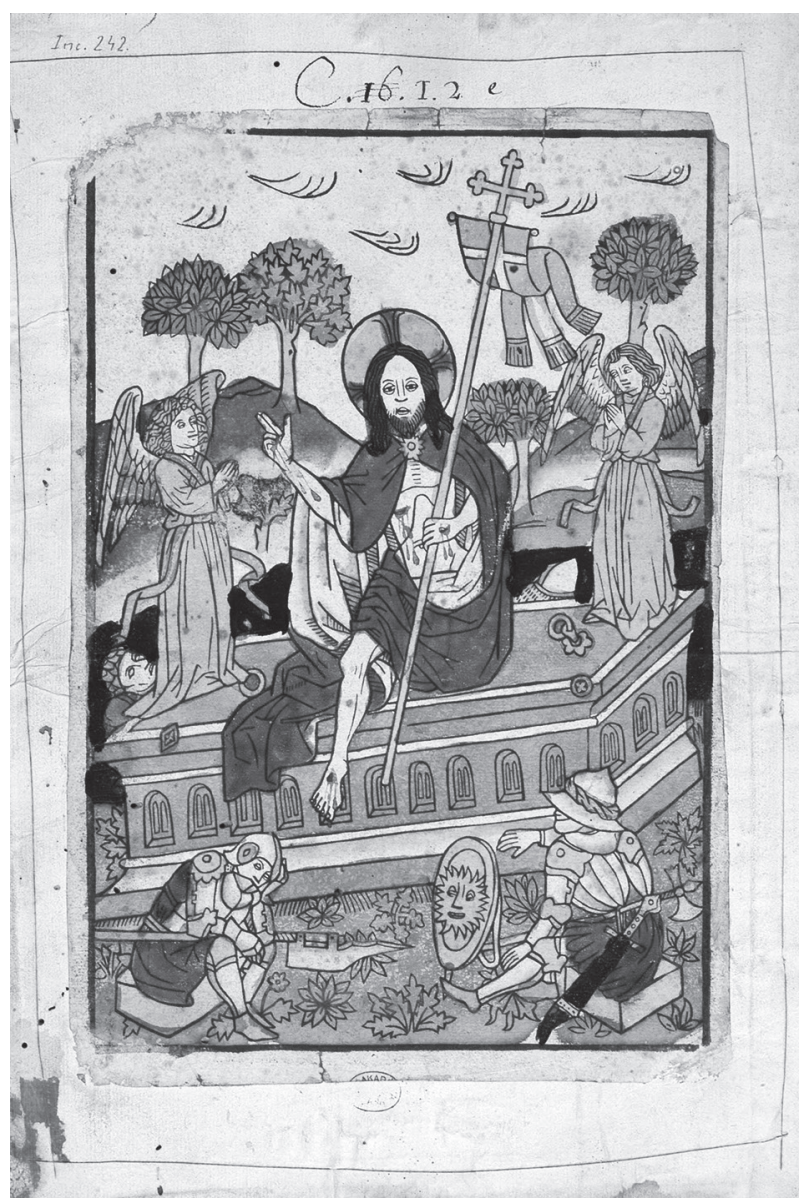

Fig. 19. South German master: Resurrection, woodcut, c. 1440 , pasted inside the binding of a 1473 Ulm edition of the Rationale divinorum officiorum; Budapest, Library of the Hungarian Academy of Sciences, Inc. 242

1440 and likely originating from Ulm (it was pasted inside an incunabula printed in Ulm), shows the same compositional solution (Fig. 19). ${ }^{51}$ This iconography was also applied on one of the last works of the Late International Style in Nuremberg, the Deocarus altar of 1437 , and is also known from several paintings in Cologne as well as from Ulm - Hans Multscher used it on the Resurrection panel of the Wurzach-altar. ${ }^{52}$ The iconographic type remained popular in Nuremberg until the mid-fifteenth century, as indicated by the Wolfgang-altar originally in St. Lorenz, the central panel of which shows the scene of the Resurrection. ${ }^{53}$ An oft-cited Hungarian parallel for the scene, the Resurrection of Christ from the Church of Saint Elizabeth in Kassa (Kaschau, today Košice, Slovakia) shows the Redeemer on top of the sealed sarcophagus, but clearly seated (with both legs present). ${ }^{54}$ The solution employed by southern German painters and by Thomas de Coloswar emphasizes the supernatural nature of the Resurrection. 


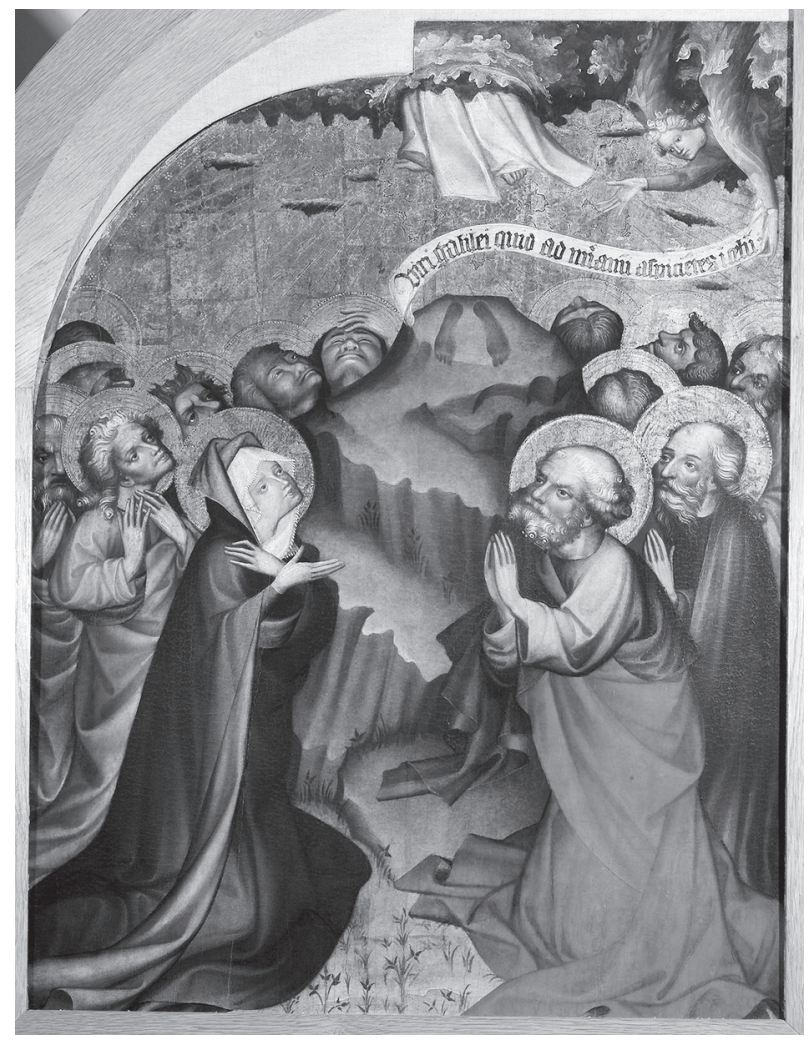

Fig. 20. Thomas of Coloswar: Ascension of Christ, 1427; Esztergom, Christian Museum (photo: Christian Museum, Attila Mudrák)

When it comes to the last scene of the narrative, the Ascension of Christ (Fig. 20), I can only make some comparisons with the arrangement of figures and of facial types, as the scene is not part of the retable of the Frauenkirche or of the other two altarpieces analyzed here. The scene is dominated by the figures of the apostles (with St. Peter in the foreground) and the Virgin Mary, while Christ already largely disappeared in the cloud above. The upward gaze of the apostles on either side of the panel is quite similar to their representation in the scene showing the miracle of the Virgin's coffin from the altarpiece of the Frauenkirche (Fig. 21). It is important to have a look at the succession of scenes on the altarpiece from Garamszentbenedek as well: the order of the scenes gives a U-shape: the narrative follows from the upper left side, and through the central Crucifixion, finishes at the upper right - so the Ascension is the conclusion of the story. The selection of the five scenes is somewhat unusual: I could not find exactly these scenes on other Passion altarpieces, except for a small south-Netherlandish tryptich dating from around 1410 and stemming from the Cistercian Convent of the Holy Cross in Rostock (today in Schwerin). ${ }^{55}$ This illustrates the more traditional arrangement, where scenes are to be read strictly from top to bottom: here on the right wing the Resurrection of Christ is shown above the Ascension (otherwise the selection of five scenes is the same). The switching of these two scenes by Thomas the Coloswar emphasises the upward motion of Christ in the scene of the Ascension, lifting him (and the viewer) up to heaven and giving a positive overall view of salvation.

\section{Stylistic connections to Nuremberg painting}

The iconographic and compositional comparisons with these altarpieces, all connected to Nuremberg, demonstrate that Thomas de Coloswar must have been familiar with the new type of Passion-altarpiece created in the environment of the imperial court of Sigismund during the first decades of the fifteenth century. This observation can be made more specific with an analysis of the style of Thomas de Coloswar. Close stylistic analogies to the work of Thomas de Coloswar can be found in paintings made in Nuremberg in the second and third decades of the fifteenth century. ${ }^{56}$ Comparisons with the high altar of the Frauenkirche itself also reveal that similar facial types, drapery forms and backgrounds were used by Thomas de Coloswar. Elements such as the grouping of figures are also similar: for example, the large groups of helmeted soldiers in the background of the Crucifixion panel of the Garamszentbenedek altar are like the group of soldiers approaching in the background of the Arrest of Christ panel in Nuremberg. The depiction of landscape backgrounds, including rocks and the miniature trees growing on them is also very similar - especially on the two images of the Agony in the Garden. However, even closer stylistic analogies to Thomas de Coloswar can be identified in the work of Nuremberg painters of the generation following the main altar of the Frauenkirche. At this time, a number of closely related workshops - all stemming from the workshop of the Frauenkirche altarpiece - worked in the imperial city. Key works of this period include the Deichsler-altar commissioned for the Dominican church of Nuremberg in 1418/1420 and the Imhoff-altar, which was made for the church of St. Sebald between 1418 and 1421. The wings of the dismembered Deichsler-altar are preserved in Berlin, and the original altarpiece had just recently been reconstructed for an exhibition at the Germanisches Nationalmuseum, following the restoration of the carved Calvary-group forming its center. ${ }^{57}$ These altarpieces were executed by a large 


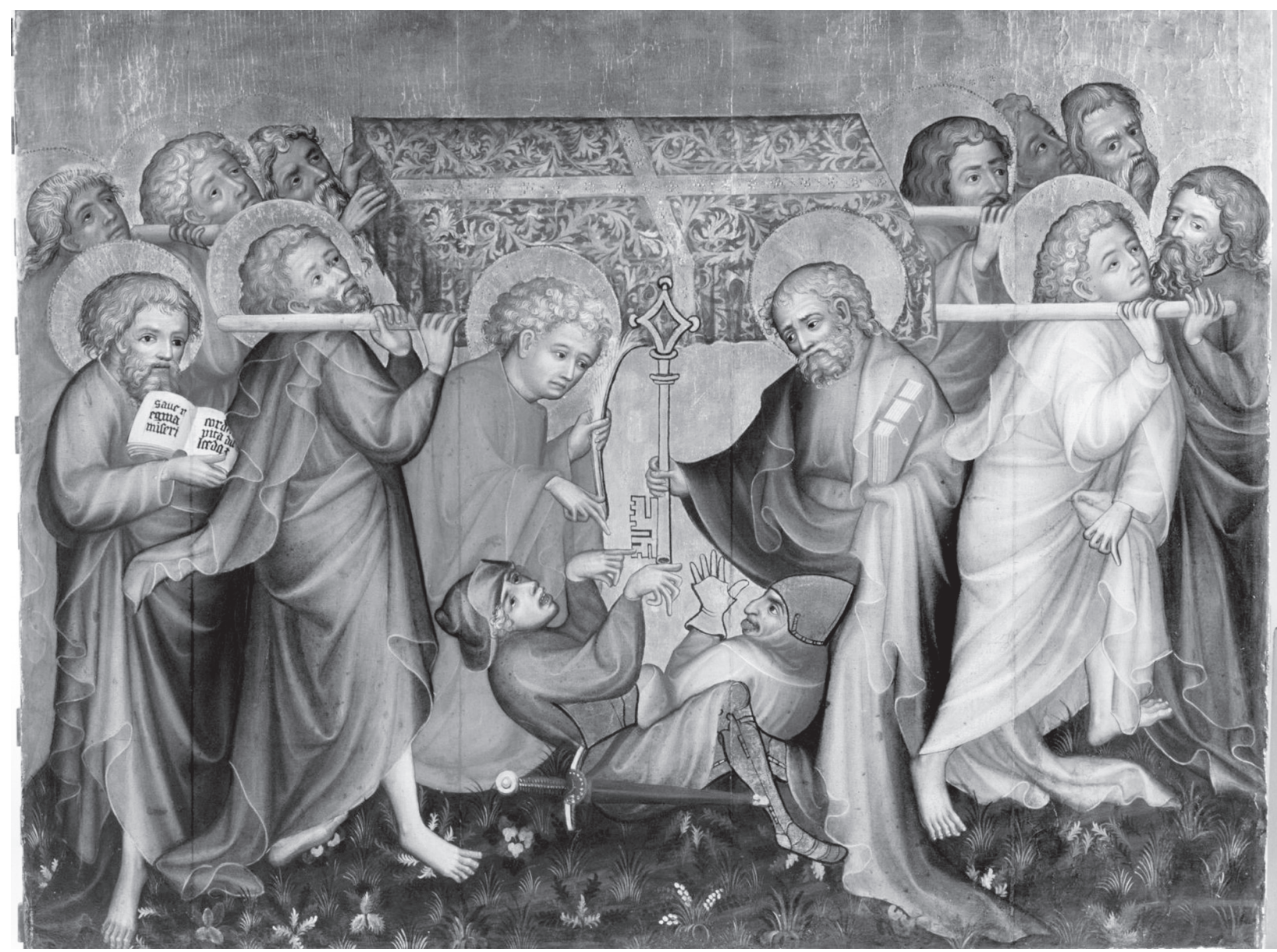

Fig. 21. The coffin of the Virgin Mary borne to burial, inside panel of the main altar of the Frauenkirche in Nuremberg, 1400-1410; Nuremberg, Germanisches Nationalmuseum

workshop, the leader of which has been named the Master of the Deichsler-Altar. According to the reconstruction of his oeuvre by Frank Matthias Kammel, he had been active since 1413 (Epitaph of Anna Imhoff, St. Sebald) until about 1430 (Death of the Virgin from Münnerstadt and Epitaph of Anna Glockengießer, St. Lorenz). ${ }^{58}$ Another of his chief works was a large altarpiece of the apostles, erected in Nuremberg's St. Sebald. The central panel of the altar shows the coronation of the Virgin, while the moveable wings depict the apostles (today in Nuremberg, St. Lorenz). The backside of the central panel, showing the Man of Sorrows, is today at the Germanisches Nationalmuseum (Fig. 22). This was executed by another painter, who can be identified with the Master of the Bamberg Altar. It appears that after working together with the Master of the Deichsler-Altar, the Master of the Bamberg Altar later established his own workshop, executing the monumental Calvary-altar for the Franciscan church of Bamberg by 1429.59 A similar occurrence can be supposed in the case of the Cadolzburg altar, painted around 1425 (today at Jagdschloss BerlinGrunewald). The altar was commissioned by Frederick VI of Hohenzollern, Margrave of Brandenburg and a major ally of Sigismund since 1409, and his wife Elizabeth. Showing a Calvary scene at the center, the altar clearly shows the influence of the Deichsler-altar, supporting the possibility that its painter stems from the same large workshop. ${ }^{60}$

A now independent panel of the Man of Sorrows supported by the Virgin Mary, held at the Germanisches Nationalmuseum and attributed to the Master of the Bamberg Altar, provides perhaps the closest analogy of the style of Thomas de Coloswar (Fig. 23). ${ }^{61}$ In the painting, which dates from around 1420, we see the same type of Christ figure as used by Thomas de Coloswar. The same elongated face was used by both painters, and even the decoration of the halo is comparable (although the lines have been emphasized with black in Nuremberg and are only incised on the Hungarian altarpiece, in the Resurrection panel, Fig. 24). We may also note the same semi-transparent loincloth 
on the Man of Sorrows - which is similar to what appears on the Crucifixion panel in Esztergom, as well as on the Bamberg altar. ${ }^{62}$ Taking this panel of the Man of Sorrows as a starting point, we can conclude that Thomas de Coloswar must have been part of the same artistic circle around 1420, and his development could have been parallel to that of the Master of the Bamberg Altar. Rooted in the artistic environment of the Master of the Deichsler-Altar, the two painters reached the top of their careers when each painted a monumental Calvary-altarpiece: one of them for the Franciscan church of Bamberg in 1429, the other for Nicholaus son of Peter in Garamszentbenedek in 1427.

The comparisons introduced above are just the first steps toward a detailed analysis, to which further observations can be added. Similarities worth exploring include the depiction of donor figures, which are usually the same diminutive figures placed inside the scenes in several examples of Nuremberg paintings, for example on the wings of the Imhoff-altar (this feature was termed archaic by Mojmir Frinta, but it clearly lived on at this time). ${ }^{63}$ Another small aspect deserves mention: it is well known (although rarely commented upon) that on almost every panel of the Garamszentbenedek painting, speech scrolls appear and emphasize the significance of scenes. This is an element generally absent from the painting of pre-Hussite Bohemia. ${ }^{64}$ While not common on the main altar of the Frauenkirche, such a scroll appears on the panel of Sts. Mary and Elizabeth, and a prominently placed scroll next to Centurion also appears on the Crucifixion fresco of the Moritzkapelle in Nuremberg. ${ }^{65}$ We see it appear next to the donors depicted on the Epitaph of Anna Imhoff (1413/15) as well. Thomas of Coloswar also painted some specific details in a similar manner as the Master of the Deichsler-Altar: the lush green grass depicted around the figure of Christ on the scene of his prayer on the Mount of Olives is just like on the exterior panels of the Deichsler-altar, under the feet of the Virgin Mary and St. Peter Martyr.

Questions remain, of course. It would be satisfying to find similar comparisons from Nuremberg for the lives of the saints on the exterior panels - otherwise the best analogies for these scenes are still those cited from the Gerona Martyrology. On the Nuremberg altarpieces cited above, the saints on the side panels are always depicted as individual standing figures, they are not incorporated into narrative scenes. However, the stylistic similarity is obvious, and some figure types and heads could be cited as analogies of Master Thomas: the figure of St. Peter martyr on the
Deichsler-altar for example is very similar to Saint Giles painted by Thomas de Coloswar. ${ }^{66}$ A comparison of technical aspects would also be useful. It has been demonstrated that Thomas de Coloswar prepared his compositions by tracing the lines of the figures by incision into the gesso of the panels. In the next step, the gold background was applied, which was decorated with punched motifs. Dotted lines made with the help of a running wheel form a lozenge pattern in the backgrounds, with freely punched motifs among them. The halos are also embellished with punched decoration. The painted surfaces sometimes depart from the incised outlines, and often cover the already prepared gold surfaces. Overall, we see signs of a technically very advanced execution and great technical proficiency. However, parallels for all these aspects are hard to find from Nuremberg: it appears that the detailed working of the gold backgrounds was much more widespread in Bohemia. ${ }^{67}$

Finally, there is one more important point of the stylistic analysis which needs to be addressed: the role of the Vienna (or Ambras) Model Book. As stated before - and more recently discussed in detail by Jan Klípa - Master Thomas must have been familiar with this collection of small-scale models of characters of the International Style. ${ }^{68}$ Klipa even assumes that the model book must have been in Buda for some time (similarly to the manuscripts of Emperor Wenceslas, brought to Buda by Sigismund). ${ }^{69}$ The connections of Thomas de Coloswar with the model book are undeniable. Most facial types of the altarpiece (including the Passion scenes) can be found on the pages of the Vienna Model Book, as already demonstrated by Gyöngyi Török several decades ago. We could interpret the model book as an important vehicle for transferring Bohemian artistic models to Thomas de Coloswar. Or else, it is time to re-examine the model book itself after all, its connections to Prague are based solely on stylistic considerations, and there is no work closer to it than the altarpiece of Thomas de Coloswar.

The style of Thomas of Coloswar, which was formed in Nuremberg at the beginning of the fifteenth century, and which also reflects the most refined prototypes of the International Gothic style in pre-Hussite Bohemia - represented by the manuscripts from the circle of the Gerona Martyrology and the Vienna Model Book - well suited the courtly atmosphere of Buda at the time of King Sigismund. ${ }^{70}$ The works cited as analogies from Nuremberg represent the counterparts of this phenomenon in the territory of the Empire. Paintings from the circle of the Master of the Deichsler- 


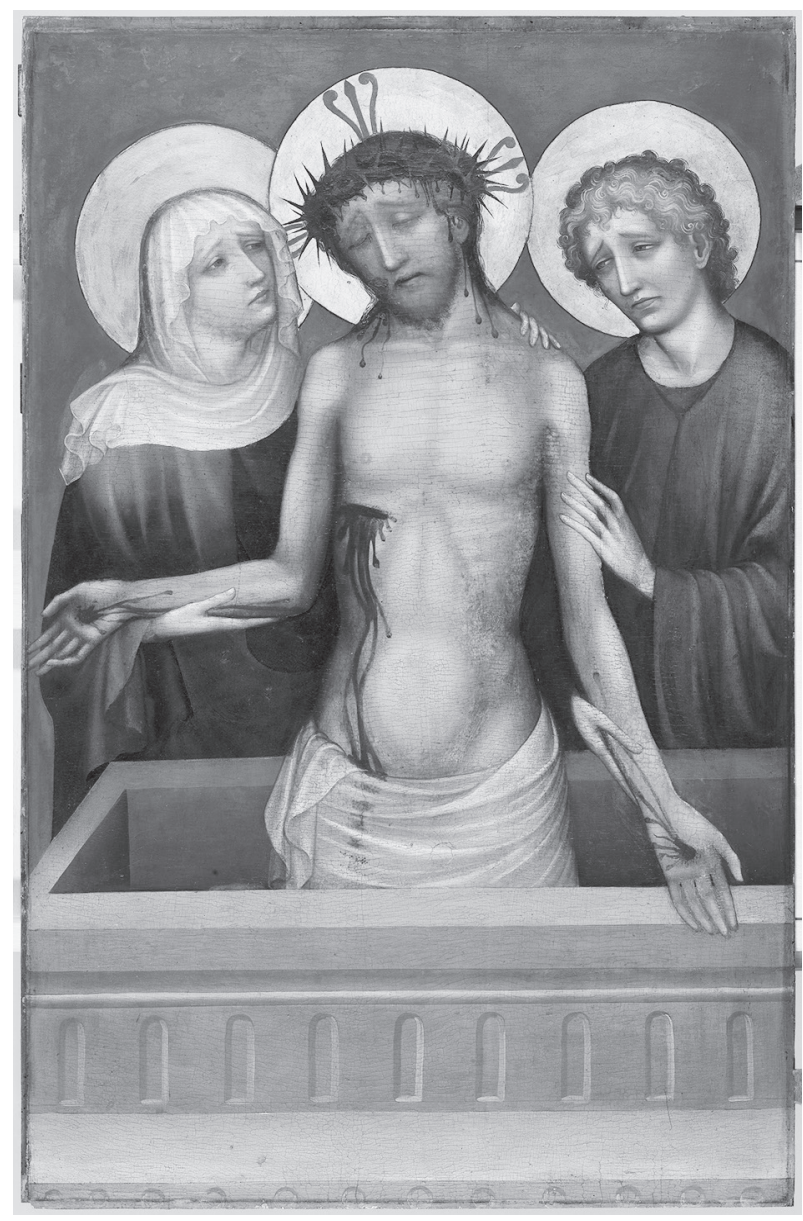

Fig. 22. Master of the Bamberg Altar: Man of Sorrows with the Virgin and Saint John, panel from the backside of the Imhoff-altar from St. Sebald, Nuremberg, 1418-1422;

Nürnberg, Germanisches Natonalmuseum

Altar reflect a court style at the time of Sigismund, specifically in the period after his coronation as King of the Romans in 1414. Wilfried Franzen writes of the Bornhofen retable that its commissioners consciously secured the painter from a far-away imperial city through Sigismund, and the altarpiece represents the new royal style in the Empire. ${ }^{71}$ Robert Suckale stated regarding the Bamberg Franciscan altarpiece that this workshop, which was based in Nuremberg, painted in a style which can be characterized as the court style of Sigismund. ${ }^{72}$ Nuremberg thus emerges as an imperial center of International Gothic painting, where the sensibilities of the Beautiful style survived even during the disastrous years of the Hussite wars in Bohemia. ${ }^{73}$

Thomas of Coloswar must have been one of the artists who transplanted this late version of the International Gothic style to Hungary. Despite large-scale destruction, especially in the center of the Kingdom of Hungary, it is worth investigating how widespread this stylistic orientation became in Hungary. Recent

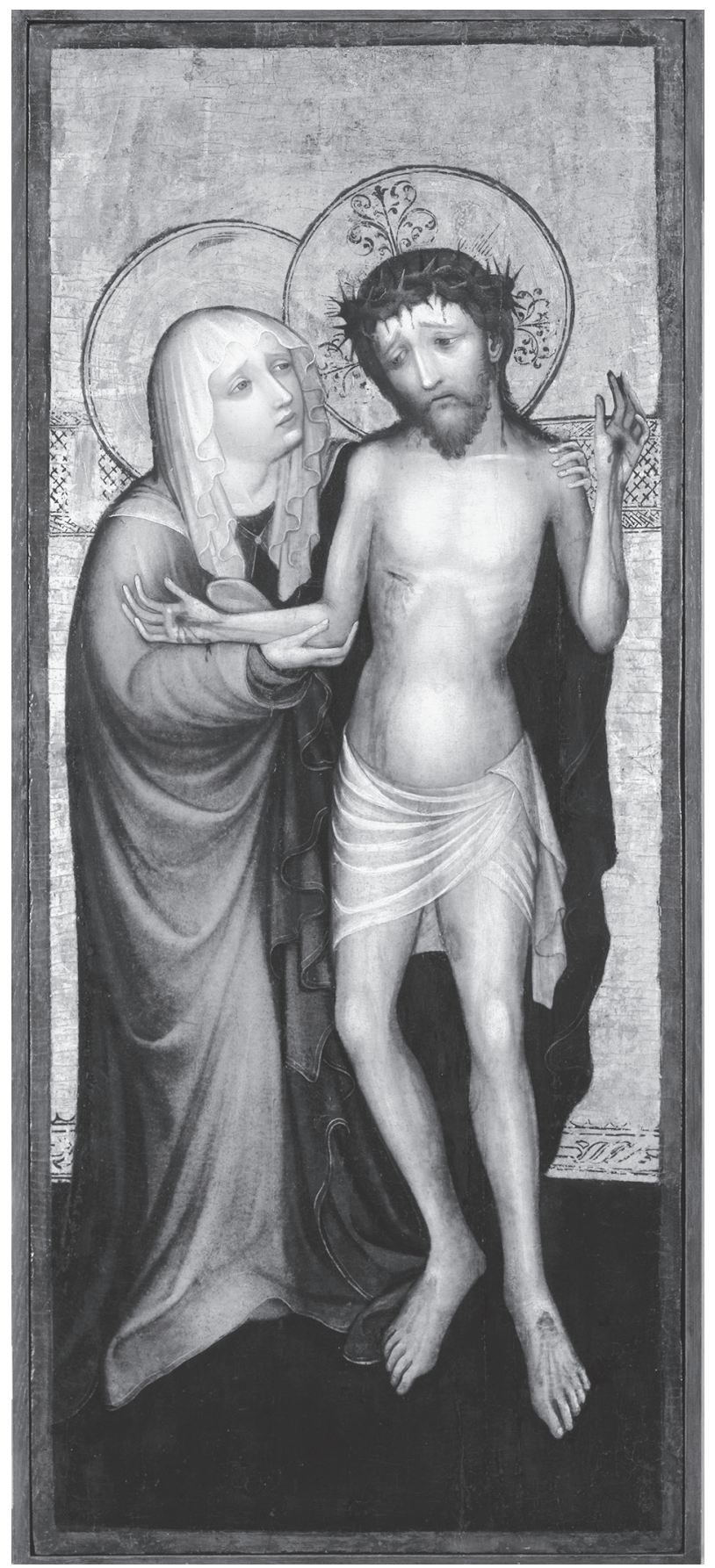

Fig. 23. Master of the Bamberg Altar:

Man of Sorrows with the Virgin, c. 1420; Nürnberg, Germanisches Natonalmuseum

discoveries make it clear that the style of Thomas de Coloswar did not exist in isolation in Hungary. I am referring to the wall paintings uncovered in the parish church of Torna (today Turña nad Bodvou, Slovakia). ${ }^{74}$ Likely commissioned by the lord of the castle and former ban of Slavonia-Croatia, Pál Besenyô of Özdöge, the frescoes date from sometime after 1409 , when he obtained the place (but most likely from 


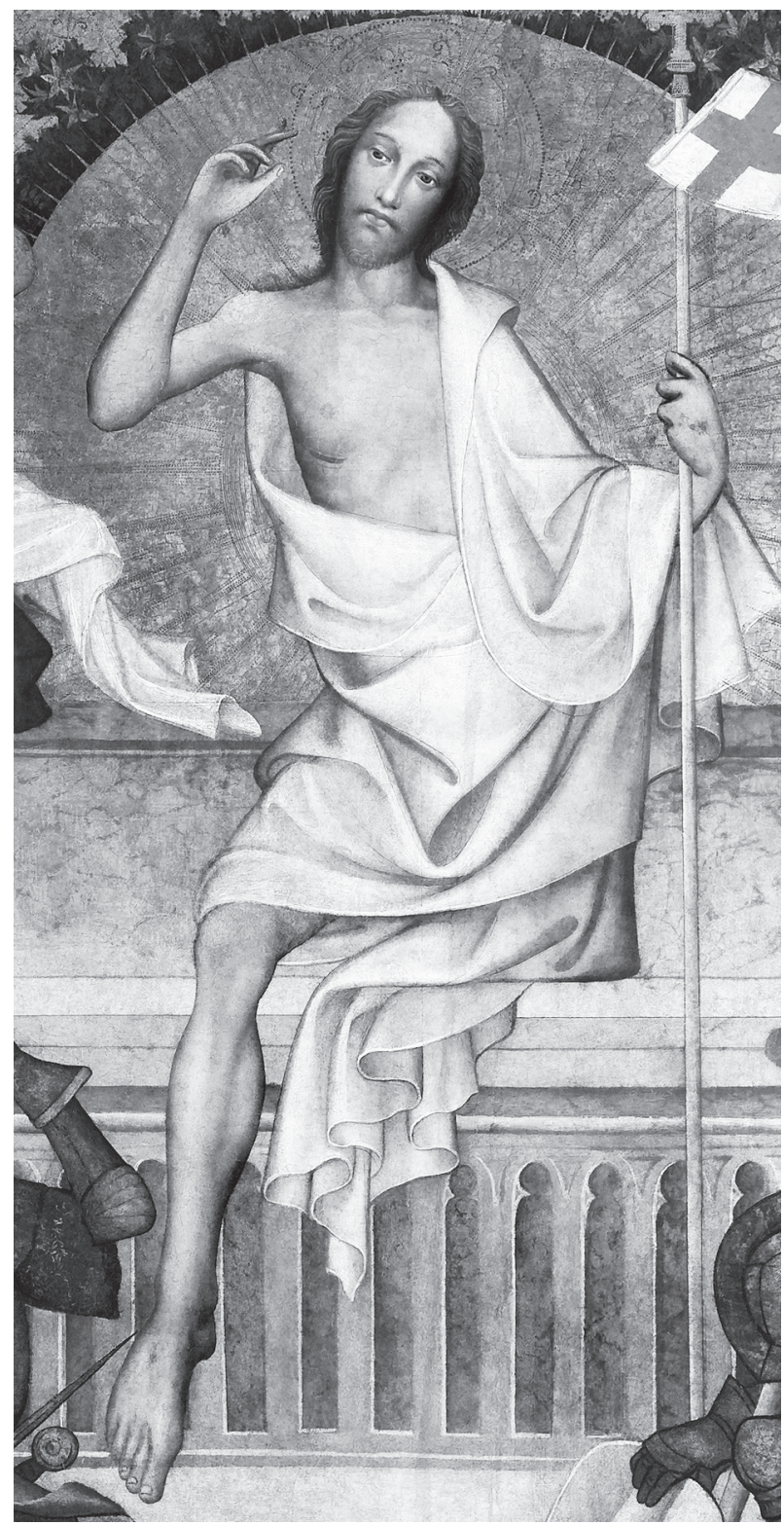

Fig. 24. Thomas of Coloswar: Resurrection, 1427 (detail); Esztergom, Christian Museum

(photo: Christian Museum, Attila Mudrák)

around 1420). The high quality - but fragmentary scenes from the life of the Virgin and the Passion of Christ represent the same stylistic orientation as the altarpiece of Thomas de Coloswar. ${ }^{75}$ Both, presumably, reflect a style common at the Hungarian court of Sigismund. Comparisons can once again be made with the altarpiece of the Frauenkirche, for example in the case of the Capture of Christ (Fig. 25). If we look at figure types and heads of figures, we find that just as in the case of Thomas de Coloswar, heads employed by the painter of the Torna frescoes represent the same types as those found in the Vienna Model Book. Other wall paintings in Hungary, which were previously described only with reference to Prague, now need to be reevaluated considering these comparisons.

The later influence of Thomas of Coloswar in Hungary is harder to grasp. There is good reason to suppose that members of the workshop of Thomas de Coloswar remained active after painting the Garamszentbenedek altarpiece, but evidence in this respect is scant. Milena Bartlová assumes that a diptych with the Annunciation and Death of the Virgin (now divided between Budapest and Nuremberg) was painted in Buda before 1430 by a member of the workshop. This is based primarily on a comparison of the apostles on the Ascension scene of the Garamszentbenedek altar with the panel showing the Death of the Virgin ${ }^{76}$ (Fig. 26). What seems more certain is that this late International Style - practiced in Nuremberg and Buda alike in the late 1420 s - formed the basis for the renewal of the figural arts at the time when Sigismund was finally able to enter Prague in $1436 .{ }^{77}$ After the Hussite period, this meant a restitution of Catholic practices, with a series of new altarpieces erected in numerous churches in Prague to replace those destroyed by the Hussites in 1421. Specifically, the newly erected altarpieces of the Church of St. James in Prague can be mentioned in this respect - panels from an altar dedicated to St. James, and another showing scenes from the life of the Virgin have been recently identified by Wilfried Franzen. The new altars in the church of St. James - the royal parish church of Prague - were consecrated in the Spring of 1437, in the presence of Sigismund. ${ }^{78}$ Stylistically, these altarpieces can be attributed to the same workshop which painted the famous Rajhad (Raigern) altarpiece, which originally stood in the church of St. Mauritius in Olomouc (Olmütz, now divided between Prague and Brno) and which dates to after $1439 .{ }^{79}$ Another altarpiece where the effect of the courtly style of the Sigismund-period is reflected is the fragmentary main altar of the Vyšší Brod (Hohenfurt) monastery. ${ }^{80}$ The style of these altarpieces represent a continuation of the art of Thomas de Coloswar, which explains the close connections between the Garamszentbenedek altar and the Rajhad altar - except their relationship is exactly the reverse than suggested in previous literature.

\section{The portrait of King Sigismund on the altarpiece}

There is one other aspect of this great altarpiece which further buttresses its interpretation in the context of Nuremberg painting: the depiction of King Sigismund 


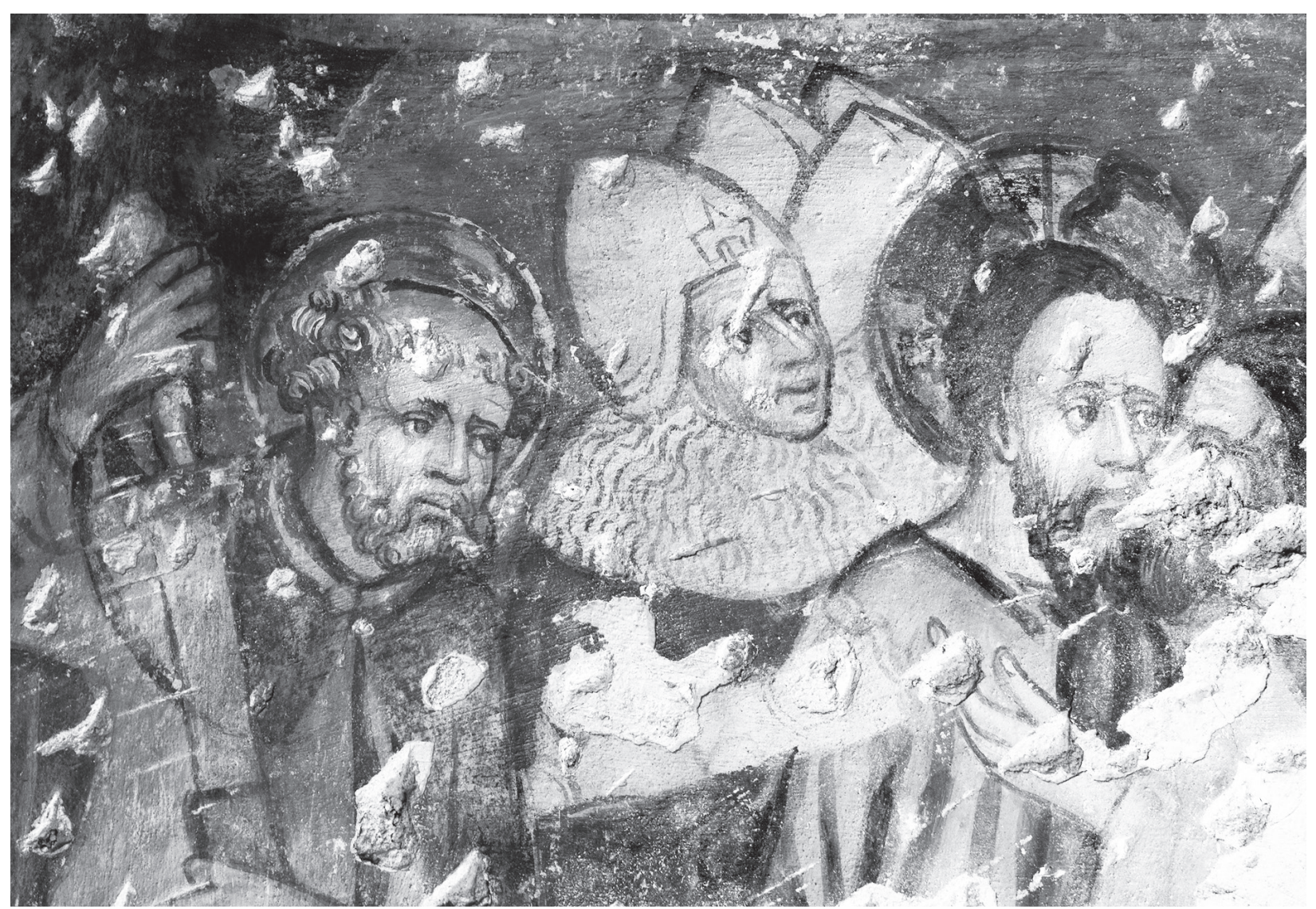

Fig. 25. Arrest of Christ, wall painting in the sanctuary of the parish church of Torna (Turňa nad Bodvou, Slovakia), c. 1420

on the central panel. It is quite obvious that the figure of the Centurion on the Crucifixion panel is a disguised portrait of King Sigismund, an identification based mainly on the facial characteristics of the figure (Fig. 29). The identification was first proposed by István Genthon in 1932, and has been generally accepted since. ${ }^{81}$ I would like to argue that Thomas de Coloswar followed a type of Sigismund-portrait which was developed in Nuremberg. It is well-known that a series of portraits were painted of the emperor during his long journeys in connection with the Council of Constance, and also later during the long decades of this reign. ${ }^{82}$ A portrait from 1414 is known from a later copy from Bern, and an entry in the account books of Frankfurt from 1438 registers payment for three Sigismund-portraits. ${ }^{83}$ As far as Nuremberg is considered, of course the famous double portrait of Charlemagne and Sigismund comes to mind, painted by Albrecht Dürer in 1512-13. ${ }^{84}$ Dürer relied on an earlier portrait of Sigismund, which is only known from a sixteenth century miniature copy included in the portrait-book of Hieronymus Beck von Leopoldsdorf. ${ }^{85}$ This analogy is more obvious if we look at the first sketch of Dürer

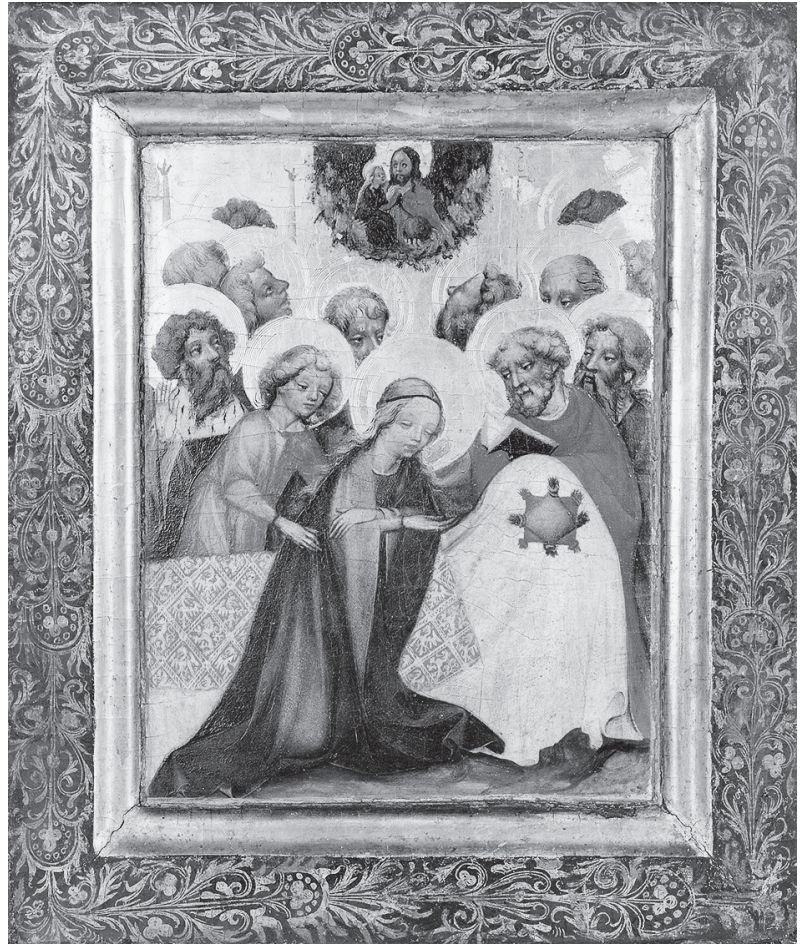

Fig. 26. Death of the Virgin, Buda, c. 1420-1430 (?); Nürnberg, Germanisches Nationalmuseum 


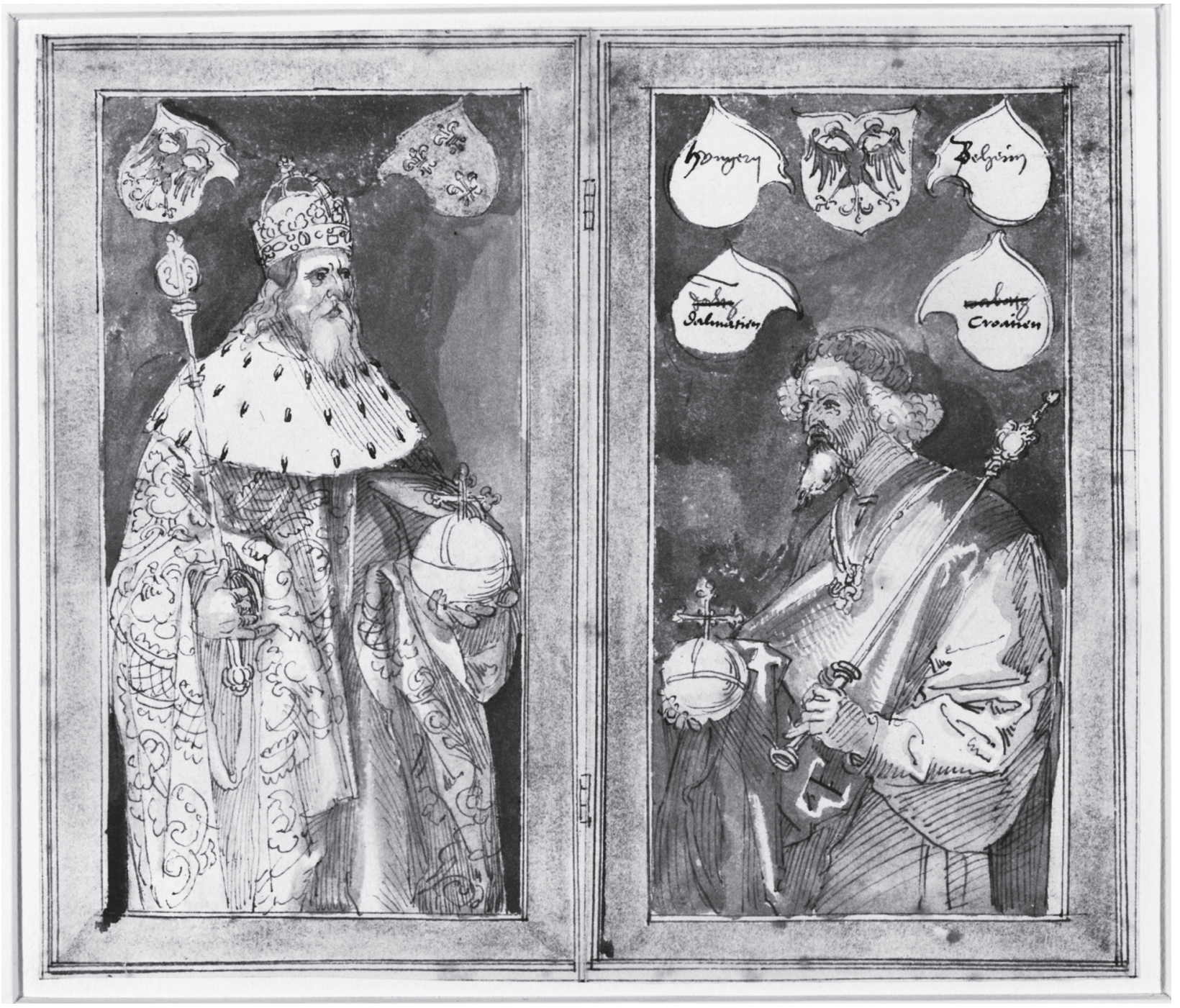

Fig. 27. Albrecht Dürer: Drawing of Emperors Charlemagne and Sigismund, c. 1507-1510; The Samuel Courtauld Trust, The Courtauld Gallery, London

(at the Courtauld Gallery, London; Fig. 27), rather than the finished portrait. Here, instead of the imaginary crown he used on the finished painting (as the Reichskrone was given to Charlemagne), Dürer shows a red diadem - while on the miniature we see a red beret with a white ermine rim. ${ }^{86}$ Although not as famous or characteristic as the great fur hat often associated with Sigismund, a combination of a red hat with a white rim is also common on Sigismund-portraits. Most of these are hidden portraits of the Emperor, where he often appears as a biblical figure, such as King David or one of the Magi. This practice was described by Eberhard Windecke in his recollections about the time of Emperor Sigismund, who mentioned two such images from his hometown of Mainz, and also stated that Sigismund was often portrayed because of his nice features. ${ }^{87}$ He was most often depicted as his patron saint, St. Sigismund. This is what we see on a fresco in the Augustinian church of Constance (Konstanz), a known crypto-portrait of Sigismund from 1417, commissioned as part of an extensive cycle by the King himself (Fig. 28). ${ }^{88}$ On the figure of St. Sigismund, the red hat has been turned into a crown, but the white rim of the hat is prominent. Another image, dating shortly after the period of the Council of Constance, can also be regarded as a disguised portrait of the Emperor: the figure of St. Sigismund on one of the wings of the Cadolzburg altarpiece (unlike other parts of the altarpiece, this wing and its companion, showing St. Urban, was destroyed in 1945). As stated above, the altar was executed by a painter from Nuremberg around 1425, and was commissioned by Burgrave Frederick of Nuremberg. ${ }^{89}$ St. Sigismund is depicted with a prominent two-pronged beard, in a hat 


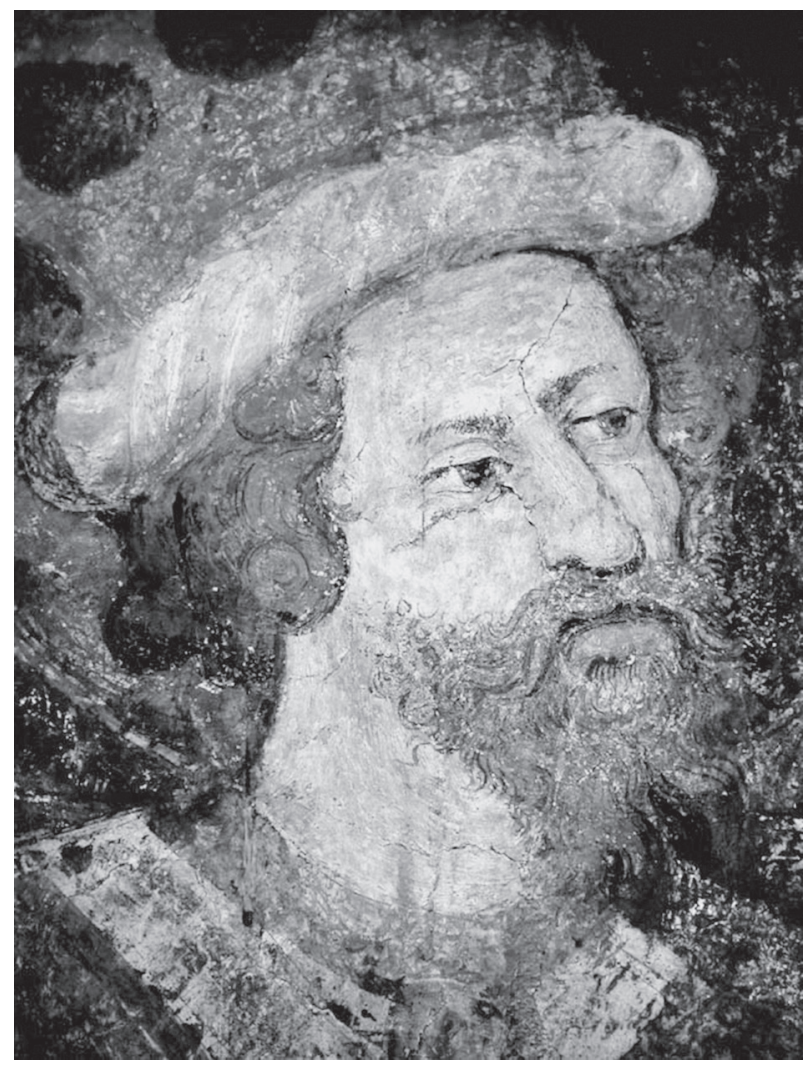

Fig. 28. Portrait of Emperor Sigismund in the guise of St. Sigismund, from the Augustinian church at Constance (Konstanz), 1417

with a wide white rim, with his hair flowing on either side. A conscious attempt to depict the patron saint of King Sigismund with his actual features can clearly be detected here. Two further disguised portraits of King Sigismund - both with a white-rimmed, pointed red hat - can be added to this list: the Centurion figures on the altarpiece of Thomas de Coloswar and on the Bamberg Crucifixion-altar from 1429 (Figs. 29-30). On both paintings, this very prominent character stands on the right side of the cross, pointing at it, recognizing the divinity of Christ (Vere filius dei erat iste - says the speech scroll of the Centurion on the Garamszentbenedek altar). The hidden portrait of Sigismund on the Bamberg altar has recently been identified by Robert Suckale - the Roman imperial association of the SPQR letters on the flag above the Centurion makes the allusion clear. ${ }^{90}$ (Previously the figure of Pilate on the exterior of the altarpiece had been identified with Sigismund, because of the fur hat - but erroneously. ${ }^{91}$ ) The representation of Sigismund on the Garamszentbenedek altar is quite similar, but here Sigismund (the Centurion) appears on horseback. Based on all the portraits from Nuremberg and its environs - from the Cadolzburg altar to Dürer's drawing of the emperor -

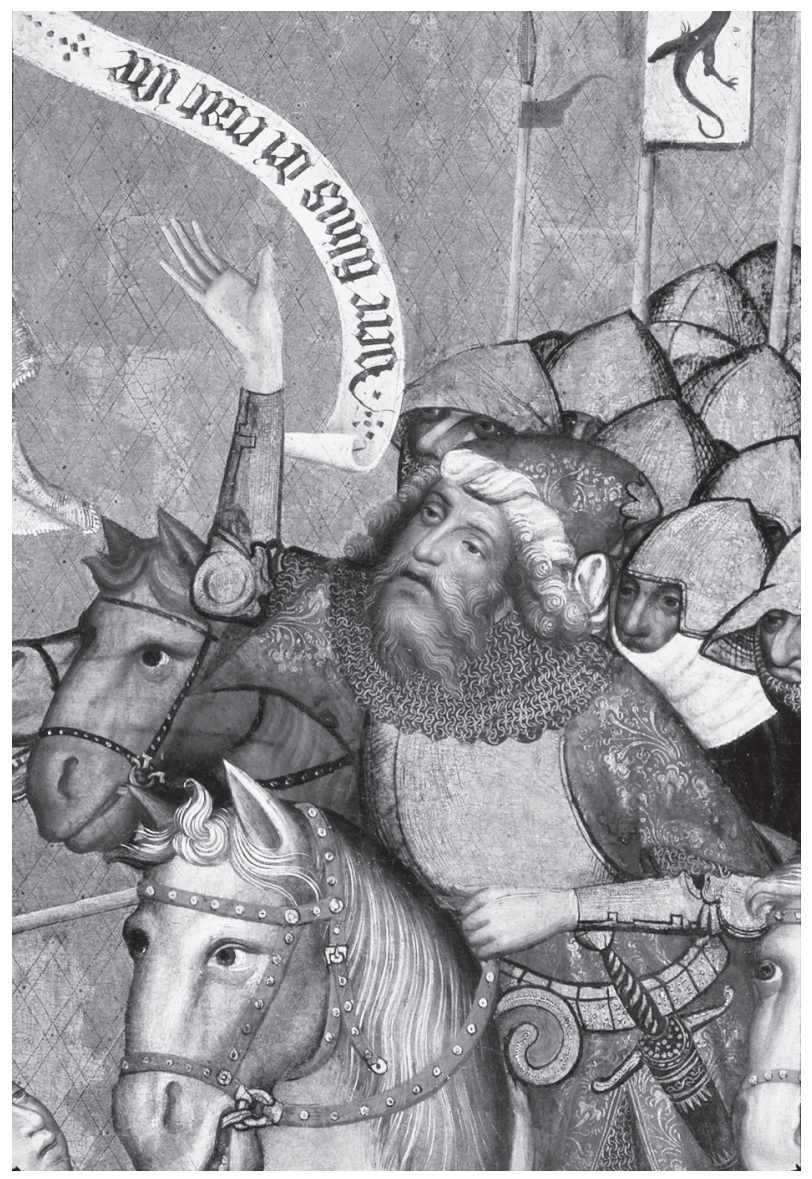

Fig. 29. Thomas of Coloswar: Emperor Sigismund in the guise of the centurio from the scene of the Crucifixion, 1427; Esztergom, Christian Museum

(photo: Christian Museum, Attila Mudrák)

it seems clear that a portrait of Sigismund once existed in this imperial town, which showed the ruler in a red-white headgear, instead of a crown or his other common attribute, the large fur hat. The portrait must have been made during one of the visits of Sigismund to the town, most likely before 1425 . His visits there in 1414 or in September 1422 should be considered as possible occasions for this. ${ }^{92}$ Thomas de Coloswar was clearly familiar with this type of representation of King Sigismund and thus included a clear reference to the emperor in the middle panel of his great altarpiece. It is perhaps worth mentioning that this type of Sigismund-portrait was also used in Hungary at another occasion: in 1424, when a drawing was made of Sigismund in Buda, in the company of the Byzantine emperor and the King of Denmark. ${ }^{93}$

Two further portrait-like figures on the central panel of the Garamszentbenedek altar need to be discussed briefly. On the left side of the cross, behind the group centered around the sorrowful Virgin Mary, Longinus appears on horseback. Having just pierced 
the side of Christ with his lance, he is just recognizing his divinity, gaining back his sight. ${ }^{94}$ The characteristic, bearded figure, with a kerchief on his head, has been identified with the poet and singer Oswald von Wolkenstein, who stood in the service of Emperor Sigismund and visited Hungary in $1425 .{ }^{95}$ It is wellknown that Oswald was blind in his right eye, as shown by his portrait painted in the beginning of his book of songs preserved in Innsbruck. ${ }^{96}$ However, I feel that this identification cannot be proven. The other portrait is the only actual representation of a living figure on the altarpiece: the donor kneeling in the left corner of the monumental image. The figure of Nicholaus son of Peter of Szentbenedek seems true to life at first. However, it is easy to find similarly painted ecclesiastical figures as donors from the period. The best comparison is from an altarpiece in Silesia, from the church of St. Giles in Wrocław (Breslau, now located in the Archiepiscopal Museum there), showing the Crucifixion. There are two donors, two canons of the cathedral, in front of the three-figure Calvary-group, praying to the crucified Christ. The older, tonsured figure on the left looks like he could be a brother of Nicholaus son of Peter: they are depicted in identical posture and outfit, their position and their features are also very much alike. The similarity is so strong, that one must think of the role of drawings in transferring compositional solutions. The painting in Breslau dates from the first half of the 1420s, and is a characteristic example of the late phase of the Beautiful Style in that town. ${ }^{97}$ In light of the above observation, I believe it needs further study, specifically its relationship with painting in Nuremberg - with the workshop of the Deichsleraltar. The only explanation I can give for the similarity is the use of the same model by the two painters, which was available to them in the form of drawings.

To sum up, I would like to propose that Thomas de Coloswar, a Hungarian painter from Transylvania, likely received the bulk of his artistic training in Nuremberg, during the first decades of the fifteenth century. This also explains the general analogies of his style to the painting of Prague as well, as painters in Nuremberg were strongly influenced by the Bohemian Soft Style. The stylistic comparisons outlined in the first part would seem to indicate that the painter must have been familiar with the painting in Nuremberg at the first decade of the fifteenth century. Connections with some later works, such as the Bornhofen altar, might mean that he was there during the second decade of the fifteenth century, and this is reinforced by his familiarity with the Nuremberg portraits of
Sigismund. The main altar of the Frauenkirche is the prime example of this connection, and Master Thomas must have worked alongside the younger painters who

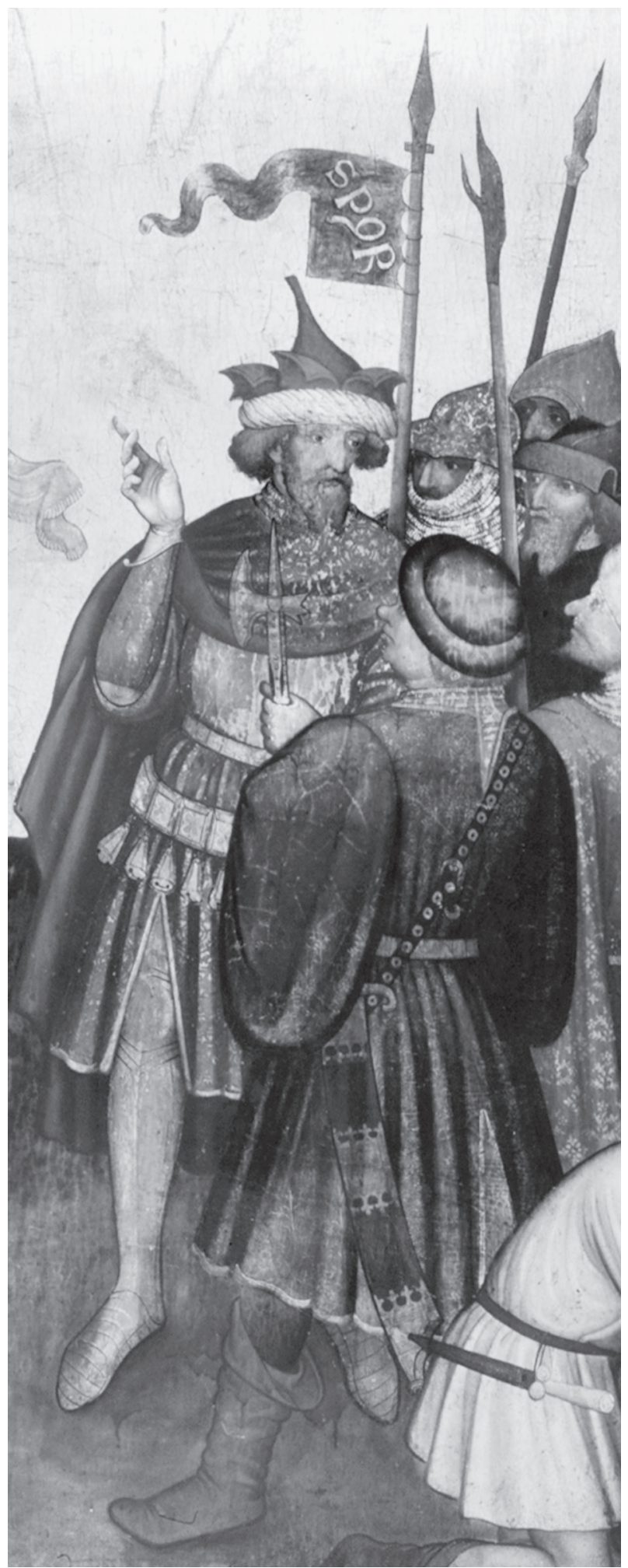

Fig. 30. Master of the Bamberg Altar: Emperor Sigismund in the guise of the centurio from the scene of the Crucifixion, 1429; München, Bayerisches Nationalmuseum 
developed in this environment, specifically the Master of the Deichsler-Altar and the Master of the Bamberg Altar. Close comparisons with painting around 1420 also fit much better with the supposed chronology of the career of Thomas de Coloswar. The very close connections between Sigismund and his favorite imperial city and birthplace would have given ample opportunities for the master to join the retinue of the king and return to Hungary looking for employment opportunities. ${ }^{98}$ Sigismund first entered Nuremberg in 1414 , on his way to his coronation in Aachen, and the Council of Constance, and it is well-documented that he brought or sent to Hungary many artists from this long trip. Illuminators from the workshop of the Gerona Martyrology also entered into his service at this time, so Thomas de Coloswar may have gotten into contact with them as well. It is well known that in 1423, a year after his lengthy second visit to the town, Sigismund placed the imperial regalia in Nuremberg, and gave the city a total of 75 privileges. The Burgrave of Nuremberg, Frederick von Hohenzollern (from 1415 the Margrave of Brandenburg) was one of the main supporters of Sigismund in the Empire, and connections between the imperial city and the court of Sigismund were also very active. In addition, the strongest faction of German citizens in Buda at this time also come from Nuremberg. ${ }^{99}$ Thomas de Coloswar thus likely returned to Buda in the service of the king, where he later received an important commission from the cantor of the royal chapel, Nicholas son of Peter. The resulting altarpiece, destined for Garam- szentbenedek, is a lasting testimony of the high level of the pictorial arts at the court of Sigismund, and also an indication that connections between Hungary and Sigismund's favourite city in the empire were more than just economic or political in nature. Locating Thomas de Coloswar in Nuremberg instead of Prague also explains that he was not a belated champion of Bohemian Soft Style, but a painter very much aware of contemporary developments and taste at imperial centers at the time of Emperor Sigismund. The style of the altarpiece represents the refined courtly manner of painting which characterized the later phase of the rule of Sigismund in Hungary, Bohemia and in other parts of the Holy Roman Empire as well, and which served as a model to the renewal of painting in Prague after 1436 .

Thomas de Coloswar thus emerges as the first of many artists in the fifteenth century whose activity indicates strong artistic connections between Nuremberg and Hungary. It is enough to mention here that another painter of Transylvanian origin, Hans Siebenbürger must have been an apprentice in the Nuremberg workshop of Hans Pleydenwurff, before settling in Vienna (and sending his pupils back to Transylvania during the last decades of the century). ${ }^{100}$ Other examples include the altarpiece of the Death of the Virgin, ordered for the church of Csütörtökhely (today Spišský Štvrtok, Slovakia) from the Master of the Tucher-Altar around 1450, ${ }^{101}$ or the case of Albrecht Dürer, whose father moved to Nuremberg from Ajtós near Gyula in Hungary in $1455 .{ }^{102}$

\section{BIBLIOGRAPHY}

Bartlová 2001 - Bartlová, Milena: Poctivé obrazy. Deskové malirstvi v Cechach a na Moravé 1400-1460, Praha, 2001.

BARTLOVÁ 2002 - Bartlová, Milena: Eine Neudatierung des sog. Raigerner altars und die Folgen für die Chronologie der böhmischen Tafelmalerei des 15. Jahrhunderts, Zeitschrift für Kunstgeschichte 65. 2002. 145-179.

BARTLOVÁ 2009 - BarTLOVÁ, Milena: Sigismundus rex Bohemiae. Royal Representation after the Revolution, in FAJT-LANGER 2009, 396-408.

BRINKMANN-KEMPERDICK 2002 - BRINKMANN, Bodo - KEMPERDICK, Stephan: Deutsche Gemälde im Städel, 1300-1500, Mainz, 2002.

Cséfalvay 1993 - Cséfalvay, Pál, ed.: Christian Museum, Esztergom, Budapest, 1993.

Exh. Cat. Bratislava 2003 - Dejiny slovenského výtvarného umenia - Gotika, ed. BuRAN, Dušan, Bratislava: Slovak National Gallery, 2003.
Exh. Cat. Budapest-Luxemburg 2006 - Sigismundus Rex et Imperator. Kunst und Kultur zur Zeit Sigismunds von Luxemburg, 1387-1437, ed. TAKÁCS, Imre (Exhibition Budapest, Museum of Fine Arts - Luxemburg, MNAH, 2006), Mainz, 2006.

Exh. Cat. Legnica-Prague 2006 - Silesia, a Pearl in the Bohemian Crown. Three Periods of Flourishing Artistic Relations, eds. Niedzielenko, Andrzej - VlnAs, Vit, Prague, 2006.

Exh. Cat. New York 2005 - Prague, the Crown of Bohemia, 1347-1437, eds. Boenm, Barbara Drake - FAJT, Jiři, New York: Metropolitan Museum, 2005.

Exh. Cat. Nürnberg 2016 - Der Deichsler-Altar. Nürnberger Kunst um 1420, ed. Kammel, Frank Matthias, Nürnberg: Germanisches Nationalmuseum, 2016.

Exh. Cat. Prague 2006 - Karl IV. Kaiser von Gottes Gnaden. Kunst und Repräsentation des Hauses Luxemburg 1310-1437, ed. Fajt, Jiři, (Exhibition in Prague, NG), München-Berlin, 2006. 
Exh. Cat. Prague-Nürnberg 2016 - Kaiser Karl IV. 13162016. Erste Bayerisch-Tschechische Landesaustellung (Exhibition in Prague, NG - Nürnberg), eds. FAJT, Jiři, Hörsch, Markus, Prague, 2016.

Exh. Cat. Rotterdam 2012 - The Road to Van Eyck, eds. KemPERDick, Stephan - Lammertse, Friso, Rotterdam: Museum Boijmans Van Beuningen, 2012.

Exh. Cat. Wien 1990 - Prag um 1400 - Der Schöne Stil. Böhmische Malerei und Plastik in der Gotik, Wien, 1990.

FAJT-LANGER 2009 - Kunst als Herrschaftsinstrument. Böhmen un das Heilige Römische Reich unter den Luxemburgern im Europäischen Kontext, eds. FAJT, Jiři, - LANGER, Andrea, Berlin-München, 2009.

FRANZEN 2002 - FranZEN, Wilfried: Die Karlsruher Passion und das "Erzahlen in Bildern". Studien zur süddeutschen Tafelmalerei des 15. Jahrhunderts, Berlin, 2002.

FRANZEN 2006 - FRANZEN, Wilfried: Römischer Kaiser und König von Böhmen - Rückkehr zu Prager vorbildern, in Exh. Cat. Prague 2006, 595-607.

FranzEN 2009 - FranZEN, Wilfried: Das Bornhofener Retabel, Johann IV. von Katzenelnbogen, und die Hofkunst Sigismunds von Luxemburg, in FAJT-LANGER 2009, 424-439.

FRINTA 1996 - FRINTA, Mojmir: Some Thought-provoking Musing: Angevin - Luxemburgian - Corvinian, Ars 29. 1996. 73-88.

FRINTA 2007 - FRINTA, Mojmir: Observations on the Altarpiece of Thomas de Coloswar, Ars 40. 2007. 3-18.

Galambos 2006 - Galambos, Éva: The Calvary Altarpiece by Thomas de Coloswar: Some Technical Observations, in PAULY-REINERT 2006, 358-371.

GENTHON 1932 - GentHON, István: Régi magyar festômũvészet [Old Hungarian Painting], Budapest, 1932.

Gerevich 1923 - Gerevich, Tibor: Kolozsvári Tamás, az elsô magyar képtábla-festô [Thomas von Kolozsvár, (Klausenburg), der erste ungarische Tafelmaler], Budapest, 1923.

Grossmann 2007 - Mittelalter. Kunst und Kultur von der Spätantike bis zum 15. Jahrhundert, ed. GrossmanN, Ulrich, Nürnberg, 2007 (Die Schausammlungen des Germanischen Nationalmuseums, Band 2.)

JANTZEN 1997 - JANTZEN, Sigrun: Der Marienaltar im Germanisches Nationalmuseum Nürnberg im Kontext der zeitgenössischen altaraufbauten (Europäische Hochschulschriften), Frankfurt, 1997.

Jenni 2006 - Jenni, Ulrike: Das Porträt Kaiser Sigismunds in Wien und seine Unterzeichnung. Bildnisse Kaiser Sigismunds als Aufträge der Reichstädte, in PAULY-REINERT 2006, 285-300.

KÉRY 1972 - KéRY, Bertalan: Kaiser Sigismund. Ikonographie, München-Wien, 1972.

Klípa 2012 - Klípa, Jan: ymago de praga. Desková malba ve střední Evropẽ, 1400-1430, Praha, 2012.

KNAUZ 1890 - KnAUZ, Nándor: A Garam melletti SzentBenedeki apátság [The Benedictine Abbey by the river Garam], Budapest, 1890.

LÖCHER 1986 - LÖCHER, Kurt: Tafelmalerei in Nürnberg: 1350-1550, in Nürnberg 1300-1550, Kunst der Gotik und Renaissance, Nürnberg - New York, 1986, 81-87.

LuKács 1973 - LuKÁcs, Zsuzsa, Kolozsvári Tamás Passiósorozatának burgundiai kapcsolatai [Burgundian Connections of the Passion-cycle of Thomas de Coloswar], Épités- Épitészettudomány 5. 1973. 331-339.

Marosi 1995 - Marosi, Ernô: Kép és hasonmás - Mũvészet és valóság a 14-15. századi Magyarországon [Image and
Likeness - Art and Reality in the 14th and 15th Centuries in Hungary], Budapest, 1995.

Mucsi 1978 - Mucsi, András, The Calvary Altar-piece of Thomas de Coloswar in the Esztergom Christian Museum, Budapest, 1980 [= Der Passionsaltar des Thomas de Coloswar im Christlichen Museum zu Esztergom, Budapest, 1978]

Oberhaidacher 2012 - Oberhaidacher, Jörg: Die Wiener Tafelmalerei der Gotik um 1400. Werkgruppen - Maler Stile, Wien-Köln-Weimar, 2012.

PAULY-ReINERT 2006 - Sigismund von Luxemburg, Ein Kaiser in Europa. Tagungsband des internationalen historischen und kunsthistorischen Kongresses in Luxemburg, 8.-10. Juni 2005, eds. Pauly, Michel - Reinert, François, Mainz, 2006.

Poszler 2006 - Poszler Györgyi: Tafelmalerei in Ungarn unter Sigismund von Luxemburg, in Exh. Cat. Budapest-Luxemburg 2006, 514-528.

RadoCSAY 1955 - RADOCSAY, Dénes, A középkori Magyarország táblaképei [Panel Paintings of Medieval Hungary], Budapest, 1955.

RAdOCSAY 1963 - RAdOCSAY, Dénes, Gothic Panel Painting in Hungary, Budapest, 1963 [= Gotische Tafelmalerei in Ungarn, Budapest, 1963].

Stange 1936 - Stange, Alfred: Deutsche Malerei der Gotik, II, Die Zeit von 1350 bis 1400, Berlin, 1936.

StAnge 1961 - StAnge, Alfred: Deutsche Malerei der Gotik XI - Österreich und der ostdeutsche Siedlungsraum von Danzig bis Siebebürgen in der Zeit von 1400 bis 1500, Berlin, 1961.

Strieder 1993 - Strieder, Peter: Tafelmalerei in Nürnberg, 1350 - 1550, Königstein in Taunus, 1993.

SuCKALE 2003 - SuCKale, Robert: Stil und Funktion. Ausgewählte Schriften zur Kunst des Mittelalters, eds. SCHMIDT, Peter - WedEKIND, Gregor, Berlin-München, 2003.

Suckale 2009 - Suckale, Robert: Die Erneuerung der Malkunst vor Dürer, 1-2. Petersberg, 2009.

TAKÁCS 2001 - TAKÁCS, Imre, The Church at Garamszentbenedek and Its Liturgical Fittings, in Paradisum plantavit - Bencés monostorok a középkori Magyarországon Benedictine Monasteries in Medieval Hungary, ed. TAKÁcs, Imre, Pannonhalma, 2001, 625-633 (Hungarian text, with illustrations: 159-186).

TÖRÖK 1978 - TÖRÖK, Gyöngyi: Táblaképfestészetünk korai szakasza és európai kapcsolatai [Early phase and European connections of Hungarian panel painting], Ars Hungarica 6. 1978. 7-27.

TÖrÖK 1989 - TÖRÖK, Gyöngyi: Problems of Central European Art, c. 1400: The Thomas de Coloswar Altarpiece in Hungary, in World Art - Themes of Unity in Diversity. Acts of the XXVIth International Congress of the History of Art [Washington, 1986], I-III, ed. Lavin, Irving, University Park - London, 1989. I. 133-138.

TörÖK 1990 - TÖrÖK, Gyöngyi: Zur Frage der Internationalität in der gotischen Buch- und Tafelmalerei, in Internationale Gotik in Mitteleuropa, eds. Pochat, Götz WAGNER, Brigitte, Graz, 1990. 50-61. (Kunsthistorisches Jahrbuch Graz 24)

Weilandi 2009 - Weiland, Gerhard: Das Hochaltarretabel der Nürnberger Frauenkirche. Ein Hauptwerk der Kunst um 1400. Standortstudien V, in FAJT-LANGER 2009. 196-221. 


\section{NOTES}

${ }^{1}$ Esztergom, Christian Museum, Inv. 54.3 - 54.10. I will use the name of the painter throughout this paper in the form it was written on the altarpiece: Thomas de Coloswar. Generally a translation of this name into modern languages - so Tamás Kolozsvári or Thomas von Klausenburg or even Tomás̆ v Kluže, etc. - is used in the literature. The name of course just means Thomas from Kolozsvár (= Klausenburg, today Cluj-Napoca, Romania), confusion is caused by the multiple names of the town.

${ }^{2}$ For a brief introduction to the altarpiece, see these most recent catalogue entries: CsÉFAlvay 1993, 172-174 (entry by Gyöngyi TÖröK); Exh. Cat. Bratislava 2003, 698-699, cat. 4.18 (entry by Milena BarTlová); Exh. Cat. BudapestLuxemburg 2006, 580-586, cat. 7.19 (entry by Györgyi Poszler); Exh. Cat. New York 2005, 308-310, cat. 146 (entry by Wilfried Franzen); Exh. Cat. Prague 2006, 583-583, cat. 212 (FrANZEN). See now also the online catalogue of Hungarian, Austrian and German medieval paintings in the Christian Museum in Esztergom, edited by SARKADI-NAGY, Emese: http://www.keresztenymuzeum.hu (2017, last accessed October 30, 2017). Detailed earlier catalogue entries: GENTHON, István, Esztergom müemlékei I., Budapest, 1948 (Magyarország múemléki topográfíja I/1.) 15-22; RADOCSAY 1963, cat. 1-7; Boskovits, Miklós - Mojzer, Miklós - Mucsi, András: Christliche Museum von Esztergom (Gran), Budapest, 1965. 116-121.

3 See TAKács 2001, 628-631; PAPP, Júlia: Kolozsvári Tamás garamszentbenedeki oltára feliratának 19. század eleji említésérôl, Ars Hungarica 27. 1999. 419-422; KNAUZ 1890, pl. 9. On the Museum, see MoJzer, Miklós: Tanulmányok a Keresztény Múzeumban, I. [Studies in the Christian Museum], Mũvészettörténeti Értesítô 13. 1964. 214-226; ProkoppNÉ STEngl, Marianne: A Keresztény Múzeum első évtizedei, Esztergom Évlapjai - Annales Strigoniensis 1. 1960. 89-101.

${ }^{4}$ Storno's drawing was made in 1885 , it is preserved in the Sopron Museum, notebook 66. of Ferenc Storno. A print made of it was published by KNAUZ 1890, plate 9.

${ }^{5}$ The inscription reads: Ite $(m)$ istam Tabulam fecit fieri honorabil(is) vir d(omi)n(us) Nico / laus de s(anc) to ben(e) $d(i) c(t)_{0}$, fili(us) Pet $(r i) d(i) c(t) i$ petws $L(e) c t o r$ et Cano(n)icus ecc(lesi)e / Jaurien(sis) Cantor q(ue) Capelle Regie maiestatis, per ma / gistru $(m)$ Thoma $(m)$ pictore $(m)$ de Coloswar.

Ad honore ( $m$ ) sancte et $i(n)$ dividue t(ri)nitatis et v(ir)ginis mat (ri) s / glo(rio)se, et s(an)c(t)i Egidi, et o(mni)um s(an)c(t)or(um), ut ip (s)i i (n)t(e)r(c)ed(ere) digne(n)tur pro / a (n)i(m) a ei (us) et a (n) $i(m) a b(u s) p(a r) e(n) t u(m)$ et $c(o n) s a(n)$ gwineor (um), et o(mni) um b(e)n(e)f(ac)tor(um) suor(um) i(n) c(on) / sp (ec)tu d(omi)ni $n(o s) t(r) i$ ih(es)u xpi Ame(n). An (n)o. d (omi)ni.m.cccco xx. ${ }^{\circ}$ vii. ${ }^{\circ}$ - The two parts of the text are separated by the coat of arms of Sigismund, King of the Romans.

${ }^{6}$ TAKÁCS 2001, 175-180, 630.

${ }^{7}$ GEREVICH 1923 (in addition to referring to Cologne, he mentions Gentile da Fabriano and northern Italian painters). Originally published as a study in 1922: GEREVICH, Tibor, Kolozsvári Tamás, az elsô magyar táblaképfestô, Országos Magyar Régészeti Társulat Évkönyve I. 1920-22. 154-188. For a brief overview of research, see: MAROsI, Ernô: Die Hofkunst unter Sigismund von Luxemburg in der Ungarischen Kunstgeschichtsschreibung, in FAJT-LANGER 2009. 44-51.
${ }^{8}$ For an overview of previous restorations and for preand post restoration photos, see GALAmBos 2006, 357-359.

${ }^{9}$ GEnTHON 1932, 36-39.

10 Seee MUCSI 1980 - stressing contacts with miniature painting and with Italian Trecento painting. Uncertainty about the master is reflected for example in the catalogue entry of the Parler-exhibition in Cologne: it is described as a chief work of Central European International Gothic, which shows Burgundian and French stylistic connections, in addition to Italian late Gothic painting and Bohemian art. Die Parler und der Schöne Stil. Europäische Kunst unter den Luxemburgern, ed. LEGner, Anton, Köln, 1978. II, 460 (Mária PROKOPP).

${ }^{11}$ Genthon 1932, 38. Genthon relied on the recent study of Johannes (János) Wilde, which identified the sitter of the famous Vienna portrait with Emperor Sigismund: WiLDE, Johannes: Ein zeitgenössisches Bildnis des Kaisers Sigismund, Jahrbuch der Kunsthistorischen Sammlungen in Wien N.F. 4. 1930. 213-222.

12 Gerevich 1923 and Genthon 1932 both mentioned Gentile da Fabriano and Lorenzo Monaco.

${ }^{13}$ LUKÁCS 1973, 331-339. Our knowledge of Burgundian and Flemish painting before Jan van Eyck is now much deeper - see for example Exh. Cat. Rotterdam 2012 - but we still cannot point to direct connections between the region and the style of Thomas de Coloswar.

${ }^{14}$ POSZLER 2006, 518-526.

${ }^{15}$ Most important publications in this respect: BALDASS, Ludwig: Eine südböhmische Malerwerkstatt um 1420, Zeitschrift für Kunstgeschichte IV. 1935. 317-319 (pointing out connections with the Raigern/Rajhad altar, which is the focus of his article); STANGE 1961, 159-161, ills. 321-323. See also: Schmid, Gerhardt: Malerei bis 1450, in Gotik in Böhmen, ed. SwobOda, K. M., München, 1969. 318.

${ }^{16}$ RadOCSAY 1955, 57-58, see also Radocsay 1963, 10ff, 45ff, Taf. 1-7.

17 TÖRÖK 1978; TÖRÖK 1989; TÖRÖK 1990.

${ }^{18}$ On the manuscript, see: FRINTA, Mojmir S.: The Master of the Gerona Martyrology and Bohemian Illumination, The Art Bulletin 46. 1964. 283-306. For a more recent analysis of the workshop, see: STUdNiČKovÁ, Milada: Las iluminaciones del Martirologio de Usuardo, in Martirologio de Usuardo, Volumen de estudios, ed. Moliero, Manuel, Barcelona, 1998. 93-162. See also Exh. Cat. New York 2005, 228-229, cat. 86.

19 See TÖrÖK 1978; TörÖK 1989; TÖRÖK 1990. For the Model Book itself, see also Exh. Cat. New York 2005, 274276, cat. 114, with earlier literature.

${ }^{20}$ Bartlová 2001, 152-153; Frinta 2007; Poszler 2006. For the Sedlec miniatures, see Exh. Cat. Budapest-Luxemburg 2006, 588-590, esp. cat. no. 7.23, 7.25 (Milada STUDNIČKOVÁ). For other pages from the Sedlec Choir Books, see Exh. Cat. New York 2005, 282-285., cat. no. 124. (Barbara DRAKE BOEHM).

${ }^{21}$ StUDniČKOVÁ, Milada: Böhmische Orientierung in der Miniaturmalerei: Der Kreis der Meister von Gerona, in Exh. Cat. Budapest-Luxemburg 2006, 529-535. See also FrinTA 1996, 73-89, where he also calls attention to the connections with armorial letters.

${ }^{22}$ For the Pozsony Antiphonal IV (Bratislava, Slovenský národný archív), see Exh. Cat. Budapest-Luxemburg 2006, 
591-592, cat. 7.26. On armorial letters issued by Sigismund to Hungarians during the period of the Council of Constance, see JÉKely, Zsombor: Armorials and Grants of Arms: Heraldic representation of Hungarian nobles at the time of the Council of Constance, in Das Konzil von Konstanz und Ungarn, ed. BÁRÁNY, Attila, Debrecen, 2016 (Memoria Hungariae 1) 155-178.

${ }^{23}$ Klípa 2012. See also the review by Gerát, Ivan in Umèni - Journal of the Institute for Art History of the Academy of Sciences of the Czech Republic 62. 2014. 179-181.

${ }^{24}$ See for example Marosi 1995, 131, 270.

${ }^{25}$ Exh. Cat. New York 2005, 308-310, cat. 146 (Wilfried Franzen), Exh. Cat. Prague 2006, 583-585, cat. 212 (Wilfried FRANZEN).

${ }^{26}$ Royt, Jan: Mistr Třeboňskeho oltáře, Praha, 2013. Cf. Chlumská, Stepánka - Fajt, Jiři: Bohemia E Central Europe, 1200-1550. The Permanent exhibition of the collection of old masters of the National Gallery in Prague at the Convent of St Agnes of Bohemia, Prague, 2006; Exh. Cat. Prague 2006, 502504, cat. 168 .

27 The new dating was proposed by BARTLOvá 2002. A date of c. 1440 is accepted in Exh. Cat. New York 2005, 319-322, cat. 154 (Wilfried FranZEN). For the earlier dating of c. 1420, see for example Exh. Cat. Wien 1990, 77-78, cat. 19.

${ }^{28}$ A comparison with the Capuchin cycle is mentioned for example by Wilfried Franzen in Exh. Cat. New York 2005, 309-310, cat. 146. For the Capuchin cycle itself, see there cat. 147 - already reflecting the proposal of Milena Bartlová for a later date for this series as well, to the period after the entry of Sigismund to Prague in 1436, see BARTLOVÁ 2001, 177-183. Cf. Exh. Cat. Wien 1990, 65-69, cat. 12.

${ }^{29}$ First Karl Oettinger called attention to similarities with Nuremberg, in an overview of literature on the topic: Oettinger, Karl: Gotische Malerei der Deutschen Südosten, Zeitschrift für Kunstgeschichte 7. 1938. 262. To my mind, a comparison with Nuremberg, specifically with the Master of the Bamberg altar was raised in the literature just one more time, in a book which had little effect in Hungary or in Bohemia: Walicki, M.: Malarstwo Polskie XV. wieku, Warszawa, 1938. 51-52.

30 Previous overviews of painting in Nuremberg before the time of Dürer: STANGE 1936; LÖCHER 1986; STRIEDER 1993.

${ }^{31}$ On the church: Roller, Stefan: Die Nürnberger Frauenkirche und ihr Verhaltnis zu Gmünd und Prag, in Parlerbauten - Architektur, Skulptur, Restaurierung. Internationales Parler-Symposium Schwaebisch Gmünd, 17.-19. Juli 2001, eds. Strobel, Richard - Siefert, Annette, Stuttgart, 2004. 229-238. For a comparison with Prague, see also: CrossLey, Paul: Our Lady in Nuremberg, All Saints Chapel in Prague and the High Choir of Prague Cathedral, in OpAčić, Zoe, ed.: Prague and Bohemia - Medieval Art, Architecture and Cultural Exchange in Central Europe. The British Archaeological Association Conference Transactions XXXII, London, 2009. 64-80; for the sculptural decoration: BRÄUTIGAM, Günther: Gmünd - Prag - Nürnberg. Die Nürnberger Frauenkirche und der Prager Parlerstil vor 1360, Jahrbuch der Berliner Museen 3. 1961. 38-75. See also Baumbauer, Benno - Fajt, Jiři: Nürnberg - die Metropole wird karolinisch, in Exh. Cat. PragueNürnberg 2016, 111-121.

32 StANGE 1936, 170-172; JANTZEN 1997. On the iconography of one of the panels of the altar, see: URBACH, Susanne: Maria und Elisabeth mit ihren Kindern - Die Nürnberger
Tafel: Genre, Erzahlung oder Symbol? in Gegegnungen mit Alten Meistern. Altdeutsche Tafelmalerei auf dem Prüfstand, eds. Kammel, Frank Matthias - Gries, Carola Bettina, Nürnberg, 2000. 39-50.

${ }^{33}$ WeILANDT 2009, 196-221.

${ }^{34}$ WeILANDT, Gerhard: Zur Herkunft der Nürnberger Tonapostel. Ein Widerspruch aus aktuellem Anlass und einige Neufunde, Kunstchronik 56. 2003. 408-414.

35 The scenes are: Massacre of the Innocents, The Virgin Mary and St. Elisabeth with Their Children, Carrying the Bier of the Virgin for Her Funeral. The fourth scene, likely depicting the Death of the Virgin, is lost. See WeILandT 2009, 200-205.

36 See for example: LÖCHER 1986, 142-143, cat. 23; JANTZEN 1997 - as fragments from the Crucifixion panel were not yet known at that time, only the other six panels are discussed. See also: HESS, Daniel: Zwischen Frankreich und Böhmen: Nürnberger Malerei und Glasmalerei, in GROssmAN 2007, 337-347, esp. 343-346.

${ }^{37}$ On these works, see Exh. Cat. Prague 2006, 418-419, cat. 135 (Grudziądz altar); Exh. Cat. Legnica-Prague 2006, 60-62, cat. I.2.31 (Strzegom panel). The spread of the Bohemian version of the Beautiful Style is the topic of KLípA 2012, on Nuremberg: 55-101.

38 The painter was based in Nördlingen, and travelled to Bornhofen to execute the altarpiece: FRANZEN 2009, 433434. See also Franzen 2006, 600.

${ }^{39}$ FRANZEN 2009.

${ }^{40}$ A detailed analysis is provided by SuCKaLe 2009, 26-34.

${ }^{41}$ LÖCHER 1986, 81-87. For the Passion-images, see also: SuCKALE, Robert: Süddeutsche szenische Tafelbilder um 1420-1450. Erzahlung im Spannungsfeld zwischen Kultund Andachtsbild, in SUCKALE 2003, 59-85. (originally written in 1988); Developments of passion iconography around the middle of the fifteenth century were discussed in more detail in a dissertation supervised by Suckale: FRANZEN 2002.

42 BRINKMANN-KEMPERDICK 2002, 55-65.

${ }^{43}$ Galambos 2006, 358-359, fig. 6.

${ }^{44}$ SCHMIDT, Gerhardt, Die österreichische Kreuztragungstafel in der Huntington Library, Österreichische Zeitschrift für Kunst und Denkmalpflege 20. 1966. 1-15; TÖRÖK 1978, 13.

${ }^{45}$ The two fragments entered the Germanisches Nationalmuseum on permanent loan in 2005, and are already included in the reconstruction by WeILANDT 2009. See also: GROSSMANN 2007, 343-345; 434, cat. 459.

${ }^{46}$ SuCKALE 2009, 16-26. Monumental multi-figure Crucifixion images also became popular in Austria, this was analyzed in detail in connection with the Linz Crucifixion, the most important work of the Viennese great workshop, painted around 1435 (Linz, Oberösterreichischen Landesmuseum): OBerHAIDACHER, Jörg: Der Linzer Kreuzigung als Beispiel für die Spätzeit der Tafelmalerei der internationalen Gotik in Wien, Österreichische Zeitschrift für Kunst und Denkmalpflege 56. 2002. 226-238, cf. OBERHAIDACHER 2012.

${ }^{47}$ For the Klosterneuburg altar, see most recently SCHLIE, Heike: Vom Ambo zum Retabel - Das Klosterneuburger Goldschmiedewerk von Nikolaus von Verdun, Zeitschrift für Kunstgeschichte 80. 2017. 247-272. For the KaufmannCrucifixion: Exh. Cat. New York 2005, 132-133, cat. 1. The same type of multifigural Crucifixion with just one cross is represented by one panel of a small diptych in Berlin, dating from around 1380, Exh. Cat. Prague 2006, 513-514, cat. 
176 (Berlin, Gemäldegalerie). Usually believed to be Bohemian, Mojmir Frinta attributes it to a Hungarian master, see FRINTA 1996

${ }^{48}$ Wall paintings from several periods are known from this destroyed chapel, based on photographic documentation. The Crucifixion fresco (likely located on the north wall of the sanctuary) dates from 1400-1410, see SCHÄDLERSAUB, Ursula: Gotische Wandmalereien in Mittelfranken. Kunstgeschichte, Restaurierung, Denkmalpflege, München, 2000 (Arbeitshefte des Bayerischen Landesamtes für Denkmalpflege, Band 109) 135-136. On earlier frescoes of the chapel, attributed to Sebald Weinschröter, see Exh. Cat. Prague-Nürnberg 2016, 440-442, cat. 10.6.

${ }_{49}$ Mojmir Frinta for example describes the motif a clear mistake (a "strange lapse in the representational logic"), FRINTA 2007, 7-8. This is already refuted by PoszLER, Györgyi in Exh. Cat. Budapest-Luxemburg 2006, cat. 7.19, but without citing any analogous representations.

50 The most important analogy is the Resurrection image of the Antwerpen-Baltimore quadriptych (Antwerpen, Museum Mayer van den Bergh), which was also mentioned by LUKÁCS 1973. See: POSZLER 2006, 522-523. More recently, a new, much earlier dating (around 1380) for the quadriptych was proposed by Stephan KemperdicK, see: Exh. Cat. Rotterdam 2012, cat. 1, 114-118.

${ }^{51}$ Published by Ernô Marosi in Exh. Cat. Budapest-Luxemburg 2006, 594, ca. 7.30.

52 An example: altarpiece of the Virgin, painted around 1400, Bielefeld, Neustädter Marienkirche. See PfEIFfER, Götz J.: Die Malerei am Niederrhein und in Westfalen um 1400. Der Meister des Berswordt-Retabels und der Stilwandel der Zeit, Petersberg, 2009. 64. Cf. Corley, Brigitte: Conrad von Soest, Painter among Merchant Princes, London, 1996. 216-217. For the Deocarus altar, see StRieder 1993, 178179 , cat. 16 .

53 GeBHARDT, Carl: Die Anfänge der Tafelmalerei in Nürnberg, Strassburg, 1908. 81-82; LuTzE, Eberhard: Der Meister des Wolfgangaltars in der St. Lorenzkirche zu Nürnberg und sein Kreis, Anzeiger des Germanischen Nationalmuseums 1932/33. 8-42, ill. 13; Strieder 1993, 47.

${ }^{54}$ The wall painting at Kassa (today Košice, Slovakia), which has recently been restored, has been connected to Thomas de Coloswar before, see MARosi 1995, 132.

55 Painted around 1410, today in Schwerin, Staatliches Museum. It is a small triptych, of not very high quality the similarity is just a coincidence; see Exh. Cat. Rotterdam 2012, 232, cat. 57.

56 On the Imhoff-altar, see also: WeILANDT, Gerhard: Die Sebalduskirche in Nürnberg. Bild und Gesellschaft im Zeitalter der Gotik un Renaissance, Petersberg, 2007.

${ }^{57}$ Exh. Cat. Nürnberg 2016. For the panels, see also KeMPERDICK, Stephan: Deutsche und Böhmische Gemalde, 12301430: Gemäldegalerie Berlin. Kritischer Bestandkatalog, Petersberg, 2010. 162-167, cat. 23.

${ }^{58}$ KAMmEL, Frank Matthias: Nürnberg 1420. Der DeichslerAltar und der Schöne Stil, in Exh. Cat. Nürnberg 2016, 33-48. 59 StRIEDER 1993, 30.

${ }^{60}$ Klípa 2012, 75-79; Dilba, Carsten: Der Cadolzburger Altar und die Hohenzollern, in Texte des RECS \#9, 09/08/2017, https://recs.hypotheses.org/1559.

${ }^{61}$ Exactly this connection was noted by OeTtINGER 1938.

62 See Klípa 2012, 96-99; Exh. Cat. Nürnberg 2016, 43.
${ }^{63}$ The "painter's relative archaism," FRINTA 2007, 7. One comparison to this feature of Thomas de Coloswar should be mentioned: in the right side of the foreground of the Crucifixion panel, there are two small-scale attendants, who are not part of the group of soldiers. The hammer in the hand of one of them explains that they are, in fact, the executioners. Yet, they look like two shepherds - a nice comparison is provided by the Nativity scene from Hluboká nad Vltavom, painted by the Master of the Třeboñ Altar, where two shepherds appear in a similar arrangement on the right side of the panel. See Exh. Cat. Prague 2006, 505-507, cat. 169.

${ }^{64}$ This was noted by TótH, Sándor: Képesség és képtelenség. Tudományos kíntorna a XX: század végén, BUKSZ Budapesti Könyvszemle 10. 1998. 74.

65 Scrolls become common on paintings made in Prague after Sigismund finally entered the town in 1436: such as the Rajhad (Raigern) altar and the St. James altar, both to be discussed later in this paper, see BARTLOvá 2009, 396-408. An earlier altarpiece painted in Prague, where the painted panels display a rich play of text is the so-called Bohemian altar in the Dom of Brandenburg from around 1375, see Exh. Cat. Prague 2006, 353-355, cat. 121; Fajt, Jiři: Der Lange Schatten Kaiser Karls IV. Zur Rezeption der luxemburgischen Herrschaftsrepräsentation in den nordöstlichen Territorien des Heiligen Römischen Reichs, Prague, 2015. 64-72.

${ }^{66}$ I feel the similarity even closer than with the image of a tonsured saint from the Vienna Model Book, which is a much older, more ascetic type. See Exh. Cat. Nürnberg 2016, 32 , ill. 39

${ }^{67}$ Observations about the technical examinations of the Garamszentbenedek altar are summarized: GALAMBOS 2006. The results of these investigations are interpreted by Poszler, Györgyi, A restaurálás - mesterség, múvészet- és segédtudomány? Mũvészettörténeti Értesító 56. 2007. 43-44. Observation about painting technique and its analogies from Bohemia are made by FRINTA 2007, 12-16.

${ }^{68}$ Comparisons with the Vienna Model Book were made by TÖrÖK 1978; TÖrÖK 1989. See also Poszler 2006; KLíPA 2012, 154-170.

${ }^{69}$ KLípA, Jan: The Migration of Artists - Transfer of Ideas. The So-Called Ambras Model Book and the Question of "Influence" in Central European Art around 1400, in Art and Architecture around 1400 - Global and Regional Perspectives, eds. CiglenečKi, Marjeta - Vidmar, Polona, Maribor, 2012. 271-280.

70 SuCKALE 2009, 34. He calls the style a retrospective art, which often leads to too early dating by art historians.

${ }^{71}$ FRANZEN 2009, 433-434.

72 Both the Bamberg altar and the Garamszentbenedek altar are described as examples of court art: SUCKALE, Robert: Über die Hinfalligkeit einiger historiographischer Konzepte und Begriffe zur Deutung der Kunst Böhmens, in FAJTLANGER 2009, 39.

73 See Franzen 2006, 602-605.

${ }^{74}$ CÁp, Łubomir - GOMBOš, Peter: Nález stredovekých nástenných malieb v kostole Turni nad Bodvou, Pamiatky a Múzeá 2005/3. 43-47.

75 JÉKely, Zsombor: Painted Chancels in Parish Churches - Aristocratic Patronage in Hungary during the Reign of King Sigismund (1387-1437), in Hungary in Context. Studies on Art and Architecture, eds. TüskÉs, Anna - TóTH, Áron SzÉKELY, Miklós, Budapest, 2013. 41-58. 
${ }^{76}$ BARTLOVÁ 2009, 397. On the Annunciation panel, see also Jankovich Miklós (1773-1846) gyújteményei, ed. Mikó, Árpád, exhibition catalogue, Hungarian National Gallery, Budapest, 2002. 49-50, cat. 1 (Zsuzsa URBACH), with a wide range of dating: 1410-1430. The diptych is also often dated to around 1420, see for example FrANZEN 2006, 602.

${ }^{77}$ Franzen 2006; Franzen, Wilfried: Karls Erben: Wenzel IV. und Sigismund, in Exh. Cat. Prague-Nürnberg 2016, 253-257.

${ }^{78}$ This is discussed in more detail in BARTLOVÁ 2009, 396-408, who maintains the dating of the Rajhad altar to the 1440s or later. Sigismund entered Prague in August 1436. The cathedral of St. Vitus and the royal parish church of the town, the Church of St. James were restored first, both consecrated in the presence of the imperial couple. Before the coronation of Queen Barbara, eight altarpieces were consecrated in St. Vitus, later another eight. At the church of St. James, seven altars were consecrated in presence of the monarch on March 14th, and a few more on the next day. It is not known, how many of these altars were embellished with painted altarpieces - but this is the context of the newly reconstructed altar of St. James. For more details, see FRANZEN, Wilfried: "Quo din ecclesiis habeantur venerabiles imagines..." Zwei wiederentdeckte Jakobstafeln aus der Prager Hofkirche Sigismunds von Luxemburg? Uméní Journal of the Institute for Art History of the Academy of Sciences of the Czech Republic 58. 2010. 190-209. The Rajhad altar is dated to around 1440 by: Exh. Cat. Prague 2006, 619-621, cat. 230.

79 Bartlová 2002; Bartlová 2009. See also Bartlová 2001

${ }^{80}$ The fragmentary scene of the way to Calvary, in particular, recalls the same scene on the Garamszentbenedek altar, see BARTLOVÁ 2002, 172-174. A panel from this altar is in the Museum of Fine Arts, Budapest, showing the Nativity (Adoration of the Newborn Jesus), Inv. no. 1636, see Museum of Fine Arts, Budapest. Old Master's Gallery, Summary Catalogue vol. 3. German, Austrian, Bohemian and British Paintings, eds. EMBER, Ildikó - TAKÁcs, Imre, Budapest, 2003. 87. Milena Bartlová believes this altar to be earlier than the Rajhad altar, see BARTLOVÁ 2009, 402-403. See also Exh. Cat. Legnice-Prague 2006, 79-80, cat. I.2.52-54, dating the altar to 1430-1440. The pictures also show a rich use of speech scrolls.

${ }^{81}$ GENTHON 1932. For later evaluations, see for example VÉGH, János: Die Bildnisse Kaiser Sigismund von Luxemburg: Typus und Individuum in den Herrscherdarstellungen am Ende des Mittelalters, in Künstlerischer Austausch Artistic Exchange. Akten des XXVIII. Internationalen Kongresses für Kunstgeschichte Berlin, 15-20 Juli 1992, ed. GAEHTGENS, Thomas, Berlin, 1993. 127-138.

82 KÉRY 1972, for his portraits in imperial towns, see also JENNI 2006, 290-295.

83 KÉRY 1972, 141, 146-147.

${ }^{84}$ KérY 1972, 144-145; Exh. cat. Budapest 2006, 157158, cat. 2.7 (for the bust-size version in Berlin, Deutsches Historisches Museum). See also Kammel 2006, 482-484.

85 Jenni 2006, 293, mentioned also by Kammel 2006, 484.

${ }^{86}$ KérY 1972, 144-145; cf. PANOFSKY, Erwin: The Life and Art of Albrecht Dürer, Princeton, 1943. 132-133, ill. 176-177.

${ }^{87}$ Windecke mentions two disguised portraits of the Emperor from Mainz: in one, he was depicted as one of the
Magi, while in the other, as King David. WindECKE, Eberhard, Eberhard Windeckes Denkwürdigkeiten zur Geschichte des Zeitalters Kaiser Sigismunds, ed. Altmann, W., Berlin, 1893. 417; KÉRY 1972, 157.

${ }^{88}$ Overview after the most recent restoration: ZAHLTEN, Johannes: Die Fresken aus der Konzilszeit in der Konstanzer Dreifaltigkeitskirche, Karlsruhe, 2009 (Hefte zum Konstanzer Konzil, 1).

${ }^{89}$ KérY 1972, 46-47; KLípa 2012, 75-79. The Cadolzburg altar is mentioned by KAMmel 2006, 481 as well, but he is more cautious regarding the identification.

90 SuCKale 2009, 31.

${ }^{91}$ Bertalan Kéry, in particular, called attention to the figure of Pilate on the wings of the Bamberg altar: KéRY 1972, $175-177$.

92 The itinerary of Sigismund has been reconstructed several times, most recently ENGEL, Pál: Királyok és királynék itineráriumai, 1382-1438 [Itineraries of Kings and Queens], ed. C. То́тн, Norbert, Budapest, 2005.

${ }^{93}$ Paris, Louvre, Rotschild collection. Exh. Cat. BudapestLuxemburg 2006, 452-453, cat. 5.19.

${ }^{94}$ This motif is analysed by MAROSI 1995, 132.

${ }^{95}$ NeuHAuser, Monika - NeuHAUSER, Walter: Oswald von Wolkenstein in Ungarn. Zu einem Kryptoportät des Tiroler Dichter auf dem altar des Thomas von Klausenburg, Veröffentlichungen des Museums Ferdinandeum 70. 1990. 183-198.

${ }^{96}$ Exh. Cat. Budapest 2006, 343-344, cat. 4.44. It has to be mentioned that although the poet has no beard on the Innsbruck portrait, he was depicted bearded in his so-called Wolfenbüttel portrait (c. 1420, in Cod. Guelf. 11 Aug. $4^{\circ}$ ) and on the memorial stone erected in Brixen in 1408 - so the beard of Longinus on the Garamszentbenedek Calvary presents no problem in itself.

${ }_{97}$ Wrocław, Muzeum Archidiecezjalne, Inv. no. 27. Exh. Cat. Legnica-Prague 2006, cat. I.2.44. See also KLíPA 2012 , 34-37.

${ }^{98}$ For the connection of Sigismund with the imperial city of Nuremberg, see: KAMmEL 2006 and FrANZEN 2006, 602-606.

${ }^{99}$ On Nuremberg, see Kammel 2006 and Fleischmann, Peter: Zeremoniell und Memoria - Kaiser und Reich in Nürnberg, in Kaiser - Reich - Stadt. Die Kaiserburg Nürnberg, ed. Heinemann, Katharina, München, 2013. 27-38.

100 On the workshop of Pleydenwurff, see SuCKALE 2009. See also more specifically: SUCKALE, Robert: Der Maler Johannes Siebenbürger (um 1440 - 1483) als Vermittler Nürnberger Kunst nach Ostmitteleuropa, in Die Länder der böhmischen Krone und ihre Nachbarn zur Zeit der Jagiellonenkönige (1471-1526), ed. WeTter, Evelin, Ostfildern, 2004 (Studia Jagellonica Lipsiensia 2) 363-384.

${ }^{101}$ Exh. Cat. Bratislava 2003, 701, cat. 4.24, cf. ill. 226227. The Nuremberg origin of the painting and its connection with the drawing of the same subject was already recognized by Hoffmann, Edith: A régi magyarországi festészet nürnbergi kapcsolatai, A Gróf Klebelsberg Kuno Magyar Történetkutató Intézet évkönyve 3. 1933. 61-64 (but the overpainted condition of the panel prevented her from attributing it to the Master of the Tucher Altar).

102 EsER, Thomas: 'Geboren im königreich zu Hungern': Albrecht Dürers d. Ä. Zuwanderung nach Nürnberg als Beispiel europäischer Künstlermobilität im 15. Jahrhundert, Transit. Zeitschrift für Politik und Zeitgeschichte 2. 2008. 17-25. 